\title{
The development of a classification system for inland aquatic ecosystems in South Africa
}

\author{
DJ Ollis ${ }^{1,2,3 *}$, JL Ewart-Smith ${ }^{2,3}$, JA Day', NM Job ${ }^{4}$, DM Macfarlane ${ }^{5}$, CD Snaddon ${ }^{2,3}$, EJJ Sieben ${ }^{6}$, \\ JA Dini' and N Mbona ${ }^{7}$ \\ 'Freshwater Research, Department of Biological Sciences, University of Cape Town, Private Bag X1, Rondebosch 7700, South Africa \\ ${ }^{2}$ Freshwater Consulting Group, PO Box 43935, Scarborough 7975, South Africa \\ ${ }^{3}$ Freshwater Research Centre, PO Box 43966, Scarborough 7975, South Africa \\ ${ }^{4}$ Department of Environmental Science, Rhodes University, Grahamstown 6140, South Africa \\ ${ }^{5}$ Eco-Pulse Environmental Consulting Services, 26 Mallory Road, Hilton 3245, South Africa \\ ${ }^{6}$ Department of Plant Sciences, University of the Free State, Qwaqwa Campus, Private Bag X13, Phuthaditjhaba 9866, South Africa \\ ${ }^{7}$ South African National Biodiversity Institute, Private Bag X101, Pretoria 0001, South Africa
}

\begin{abstract}
A classification system is described that was developed for inland aquatic ecosystems in South Africa, including wetlands. The six-tiered classification system is based on a top-down, hierarchical classification of aquatic ecosystems, following the functionally-oriented hydrogeomorphic (HGM) approach to classification but incorporating structural attributes at the lower levels of the hierarchy. At Level 1, a distinction is made between inland, estuarine and shallow marine systems using the degree of connectivity to the open ocean as the key discriminator. Inland systems are characterised by the complete absence of marine exchange and/or tidal influence. At Level 2, inland systems are grouped according to the most appropriate spatial framework for the particular application. At Level 3, four primary Landscape Units are distinguished (Valley floor, Slope, Plain, Bench) on the basis of the topographic position within which a particular inland aquatic ecosystem is situated, in recognition of the influence that the landscape setting has over hydrological and hydrodynamic processes acting within an aquatic ecosystem. Level 4 identifies HGM Units, defined primarily according to landform, hydrological characteristics and hydrodynamics. The following primary HGM Units (or HGM Types), which represent the main units of analysis for the classification system, are distinguished at Level 4A: (1) River; (2) Floodplain Wetland; (3) Channelled Valley-Bottom Wetland; (4) Unchannelled Valley-Bottom Wetland; (5) Depression; (6) Seep; (7) Wetland Flat. Secondary discriminators are applied at Level 5 to classify the hydrological regime of an HGM Unit, and Descriptors at Level 6 to categorise a range of biophysical attributes. The HGM Unit at Level 4 and the Hydrological Regime at Level 5 together constitute a Functional Unit, which represents the focal point of the classification system. The utility of the classification system is ultimately dependent on the level to which ecosystem units are classified, which is in turn constrained by the type and extent of information available.
\end{abstract}

Keywords: freshwater ecosystems, hydrogeomorphic (HGM) units, inland water ecosystems, wetlands, wetland classification system

\section{INTRODUCTION}

\section{Classification and the use of classification systems}

Classification is generally taken to be the process through which similar objects are grouped together and dissimilar objects are separated from each other on the basis of predefined criteria. This is a fundamental of the thinking process in humans, creating order out of apparent chaos (Morant, 1981). It is a process that enables us to organise and begin to understand complex and variable objects, systems or ideas so that we can work with them more easily (Eekhout et al., 1997; O'Keeffe et al., 1994). There is an implicit use of classification in ecology, or in any science for that matter, because it provides a basis for distinguishing between different units of analysis (e.g. ecosystems, populations, species, genes). As a result, classification systems have been used for many years, by scientists and resource managers, to partition and organise information about complex ecological systems in an attempt to simplify our understanding of them (Naiman et al., 1992; Froude and

\footnotetext{
* To whom all correspondence should be addressed.

ฮ +2772 377 7006; email: dean.ollis@gmail.com

Received: 15 April 2013; accepted in revised form 7 October 2015
}

Beanland, 1999). In the context of aquatic ecosystems, the development and adoption of a classification system is often the starting point for the compilation of an inventory, while the information collected through aquatic ecosystem inventories is in turn regarded as a necessary prerequisite for holistic conservation and management of these ecosystems (Finlayson and Van der Valk, 1995).

The current paper describes a classification system developed for inland aquatic ecosystems in South Africa, including wetlands. Furthermore, it provides an historical overview of the development and use of classification systems for wetlands and other aquatic ecosystems in the country, and explains the theoretical basis of the classification system that has been developed. A brief discussion about the application of the classification system, with reference to a worked example, is included, and future research needs are highlighted.

It is important to recognise the difference in the use of the word 'classification' (or the phrase 'classification system'), as contemplated above, and that set out in sections 12 to 15 of South Africa's National Water Act (RSA, 1998), whereby 'classification' refers specifically to the process of categorising water resources into management classes, based on their present ecological condition and a number of other criteria, as part of a prescribed national Water Resource Classification System (DWAF, 2007a). In the current paper and in the classification 
system that it deals with, the more commonly understood meaning of 'classification' (and 'classification system') has been assumed, and not the use of the term as adopted by the National Water Act.

\section{Theoretical approaches to the development of classification systems for ecosystems}

A number of different approaches can be followed in the development of classification systems for ecosystems. Comprehensive reviews of the different approaches, in relation to inland aquatic ecosystems, are provided by Naiman et al. (1992), King et al. (1992), Hart and Campbell (1994), O’Keeffe et al. (1994), Jones (2002) and Ollis and Ewart-Smith (2006). In essence, the major dichotomies are (1) single-level vs. hierarchical classification; (2) top-down $v$ s. bottom-up classification; and (3) structural vs. functional classification. The ultimate goal of ecological classification, irrespective of which approach is followed, is to organise sets of observations or characteristics into meaningful groups based on measures of similarity or difference (Naiman et al., 1992), so as to provide a framework for organising our knowledge about ecosystems (Jensen et al., 2001). Any classification system places what are, in essence, arbitrary limits on components of the subject being classified (Morant, 1981). In the case of ecosystems, this typically involves the grouping of habitats or natural features into categories with similar characteristics, properties, or functions (Tiner 1999). Ecological systems are, however, by their very nature, generally characterised by indistinct boundaries (Eekhout et al., 1997) and are thus inherently difficult (or impossible) to consistently classify according to a limited set of criteria. The classification of streams, and of other inland aquatic ecosystems, is especially challenging, being complicated by longitudinal and lateral linkages (and vertical linkages), by changes that occur in the physical features over time, and by boundaries between apparent patches that are often indistinct (Naiman et al., 1992).

In single-level classification, ecosystems are simply divided into a series of classes or types, such as 'marsh' or 'mire' or 'swamp'. Hierarchical classification, on the other hand, is multi-tiered, with each successive level requiring more detailed information. While single-level classifications are useful for providing general descriptions of ecosystem types, hierarchical classification systems, by their nature, tend to provide more flexibility and a greater level of consistency (O'Keeffe et al., 1994; Tiner, 1999; Jones, 2002). The hierarchical approach to ecosystem classification also facilitates scaled definitions of ecosystem components and identification of the linkages between different scales of ecological organisation, thus simplifying the description and prediction of the relationships between complex ecological patterns and processes at all relevant scales of system organisation (Jensen et al., 2001). This is an important advantage of the hierarchical approach because a good classification system for ecosystems should, ideally, have the ability to encompass broad spatial and temporal scales (Naiman, 1998). There is thus general agreement that hierarchical classification is preferable to single-level classification, at least in the context of river ecosystems, both internationally (e.g. Naiman et al., 1992) and in South Africa (Eekhout et al., 1997). Examples of internationally recognised hierarchical classification systems for aquatic ecosystems are those of Frissel et al. (1996) and Rosgen (1994) for river ecosystems, and that of Cowardin et al. (1979) for 'wetlands and deepwater habitats' (including rivers).
Top-down classification uses independent physical variables (such as climate and broad-scale geomorphology) to group ecosystems, while the bottom-up approach uses emergent site-specific properties of ecosystems (such as water chemistry or the nature of the biota) to generate groupings. The top-down approach is typically easier to apply, especially at broader spatial scales, as the required information is more readily obtainable (e.g. in the form of ecoregion maps), but it does not allow for the a posteriori differentiation provided by the resource-intensive bottom-up approach. Not surprisingly, therefore, most classification systems for wetlands and other inland aquatic ecosystems are based on the top-down approach. Top-down classifications have been criticised to be of dubious value as management tools but, while bottom-up approaches based on biotic attributes of the systems 'are undoubtedly likely to result in the most useful and ecologically meaningful classifications', the development and application of bottom-up classification systems is more data intensive, expensive and time-consuming (Eekhout et al., 1997 p. 19). This dilemma can be addressed by following a mixed approach, such as that advocated for river ecosystems in Australia (Hart and Campbell, 1994), whereby a top-down classification is used to identify the spatial entities (regions) within which more rigorous bottom-up classifications can be applied to elucidate finer-scale groupings.

Classification systems can be based either on the structural characteristics such as size and the dominant substratum/ vegetation type, or on functional attributes such as hydrology, sediment transport, nutrient cycling or productivity. Functional classification systems reveal more about an ecosystem than can be inferred from structural classifications, but functional attributes are typically far more difficult to assess than structural ones. Most classification systems that have been developed for aquatic ecosystems to date thus incorporate structural rather than functional characteristics as the primary criteria for grouping similar ecosystems. Functional information is, however, far more likely to provide predictive capability (Eekhout et al., 1997) and Naiman et al. (1992) have identified the ability to integrate structural and functional characteristics as a fundamental attribute of an enduring classification system.

One of the most influential structural classifications for aquatic ecosystems, worldwide, has been the Classification System for Wetlands and Deepwater Habitats developed by the United States Fish and Wildlife Service (USFWS) (Cowardin et al., 1979) for application to the US National Wetland Inventory. This system is hierarchical, with 5 levels. The first level includes 5 'Systems', recognised on the basis of observable (or measurable) features such as salinity or surface area. The so-called Cowardin system, or classification systems derived from it, has been widely used, for instance in the typology adopted by the contracting parties to the Ramsar Convention in 1990 (Scott and Jones, 1995). Structural classifications such as these, however, distinguish between ecosystems on the basis of a mixture of vegetation, soil, inundation and landform features that are often inconsistent and have led to much confusion (Semeniuk and Semeniuk, 1995). Internationally, there is general agreement that wetland classification systems based on geomorphological and hydrological aspects are far more robust and consistent than classification systems based on structural criteria, at least at the broader levels of classification (Finlayson et al., 2002), largely because geomorphology and hydrology are recognised as the fundamental drivers that determine the existence of wetlands and their functioning (Brinson, 1993; Semeniuk and Semeniuk, 1995; Jones, 2002; Kotze et al., 2008, Ellery et al., 2008). This is the basic premise on which the hydrogeomorphic 
(HGM) classification system for wetlands was developed in the USA (Brinson, 1993), and forms the basis of the HGM approach to the classification and functional assessment of wetlands and other aquatic ecosystems internationally.

Recognising the need to better describe wetlands in terms of their hydrogeomorphic characteristics, in line with the HGM approach, the USFWS developed a set of dichotomous keys for use with National Wetland Inventory data classified according to Cowardin et al.'s (1979) classification system. These keys (Tiner, 2003, 2011) attempt to bridge the gap between the original USFWS wetland classification of Cowardin et al. (1979) and the HGM classification system (Brinson 1993). They do so by providing descriptors for landscape position, landform, water flow path and waterbody type (so called 'LLWW descriptors'), which are important for producing better characterisations of wetlands and deepwater habitats (Tiner, 2003). The

LLWW descriptors were developed primarily as additional descriptors for the existing USFWS classification system and to be applied to digital data from the USA's National Wetlands Inventory (Tiner, 2003), but they can also be used independently to describe a wetland or deepwater habitat. These HGMbased descriptors have been used by the USFWS to produce state-wide, landscape-level assessments of wetland functions for a number of states and for other large geographic areas in the USA, and certain states are using this expanded classification as the foundation for landscape-level wetland functional assessment.

Historically, HGM-based classification systems have been difficult to apply because information necessary for classification has been difficult to obtain for large-scale classification initiatives. Advances in modelling and remote sensing tools in recent years have, however, facilitated the mapping of abiotic features such as drainage, landform, gradient and hydroperiod (e.g. Davidson and Finlayson, 2007; Rebelo et al., 2009; Rebelo 2010), thus permitting the application of HGM-based classification systems to regional (e.g. De Roeck et al., 2008), national (e.g. Nel et al., 2011a, b) and global (e.g. Lehner and Döll, 2004) inventories of wetlands and other aquatic ecosystems. Furthermore, the HGM approach to classification can provide information on the fundamental processes responsible for the development of different types of aquatic ecosystems, and the principal determinants of ecosystem structure and function. The elucidation of such information has been identified on numerous occasions as being important for the management of wetlands in South Africa (e.g. Rogers, 1997; McCarthy and Hancox, 2000). The broad classification provided by the HGM approach can also be extended by the addition of descriptors for salinity, vegetation cover, shape and size (Semeniuk and Semeniuk 1995; Finlayson et al. 2002), or any other descriptors that may be of relevance to a region or for a specific purpose.

The classification system presented in this paper is based on a top-down, hierarchical classification of aquatic ecosystems based primarily on functional attributes (specifically, the HGM approach to classification) but incorporating structural attributes at the lower levels of the hierarchy.

\section{Historical overview of classification systems that have been developed for wetlands and other aquatic ecosystems in South Africa}

One of the first broad classifications of inland and estuarine aquatic ecosystems at a national level was that of Noble and Hemens (1978), who described 6 primary categories (each with a number of sub-categories), namely: (1) rivers; (2) vleis and floodplains; (3) endorheic pans and other lakes of the interior; (4) artificial impoundments; (5) coastal and estuarine lakes; and (6) estuaries and estuarine lagoons. This classification system was presumably based on an earlier, somewhat convoluted classification scheme for 'aquatic biotopes' in South Africa presented by Noble (1974). Breen and Begg (1989) presented a modified version of the original classification of Noble and Hemens (1978) in a hierarchical format, later modified by Rogers (1997) to make the classification system exclusively applicable to inland aquatic ecosystems. All of these classification systems based on the aquatic ecosystem types distinguished by Noble and Hemens (1978) were problematic to apply because of the inclusion of vernacular, non-mutually exclusive terminology (such as 'vlei', which is a common term for floodplain wetlands in certain parts of the country but encapsulates coastal lakes in other parts of the country) and a lack of precise, widely accepted definitions.

A number of classification systems have been developed and used for specific wetland or aquatic ecosystem types, and/ or for specific parts of the country. Begg (1986), for example, presented a provisional, single-level classification system, based on altitude, for wetlands in Natal. Other examples include classification systems for rivers (Brown et al., 1996; Rowntree and Wadeson, 1999, 2000; Rowntree et al., 2000); riparian wetlands (Rogers, 1995); endorheic pans of the western Free State (Geldenhuys, 1982), and of South Africa (Allan et al., 1995); coastal lakes of South Africa (Hart, 1995); peatlands of South Africa (Smuts, 1998, cited by McCarthy and Hancox 2000); wetlands of the Natal Drakensberg Park (Dely et al., 1999); inland wetlands of the Western Cape (Jones, 2002; Jones and Day, 2003); and wetlands in the upper Olifants River catchment in Mpumalanga (Marneweck and Batchelor, 2002). More recently, a river and a wetland classification system has been developed by Rivers-Moore and Goodman (2010) specifically for freshwater conservation planning in KwaZulu-Natal. In addition, nationally applicable classification systems have been developed for South African estuaries (by Whitfield, 1992 and, more recently, by Van Niekerk and Turpie, 2012) and for marine systems (by Lombard et al., 2005 and, more recently, by Sink et al., 2012). Although useful for specific applications and/or in certain portions of the country, none of these classification systems are comprehensive enough to be used for the classification of all aquatic ecosystem types throughout South Africa. Only a few classification systems have covered the full spectrum of aquatic ecosystems encountered across the country (as described below), but few of these have been widely used.

In the early 1980s, Morant $(1981,1983)$ proposed a modified version of the USFWS system (after Cowardin et al., 1979) to be used for wetland classification at a national level in South Africa. This classification system was based on a broad definition of 'wetlands', as per the Ramsar Convention, to include all inland aquatic ecosystems, estuarine systems and shallow marine systems. Somewhat later, Breen (1988) suggested using Morant's system as a prototype for a national inventory of wetlands, once testing of the system had been undertaken in the different regions of the country. Very little progress was made in documenting the variability of wetlands and other aquatic ecosystem types at a broad national scale until the resurgence of interest in and/or funding for wetland studies in the mid-to-late 1990s. At this stage, Cowan and Van Riet (1998) used an adaptation of the Ramsar classification system for a preliminary inventory of the major wetlands in South Africa. This classification system, which was based on the use of predominantly structural criteria at the primary levels (e.g. 
the presence of vegetation to identify 'palustrine' and, in some cases, 'endorheic' systems), was hampered by the inclusion of hydrological criteria (specifically tidal regime and hydroperiod, which are often unknown) to categorise specific ecosystem types (Jones, 2002).

At about the same time that Cowan and Van Riet (1998) presented their classification system, Dini et al. (1998) produced a draft classification system, later refined by Dini and Cowan (2000), for a South African National Wetland Inventory. This classification system was an adaptation of Cowardin et al.'s (1979) system, including a category for 'endorheic systems' in the first draft (Dini et al., 1998), as per the classification system of Cowan and Van Riet (1998), which was done away with in later revisions. Dini et al. (1998) and Dini and Cowan (2000) attempted to include hydrogeomorphic elements into the South African system because of an international move towards the HGM approach to aquatic ecosystem classification. This was done by introducing categories for 'flat', 'slope', 'valley bottom' and 'floodplain' (plus 'pan', 'basin' and 'fringe' in the case of the later version of Dini and Cowan, 2000), at the secondary level, for Palustrine Systems. A modified version of Dini and Cowan's (2000) classification system was used in piloting the South African national wetland inventory (Thompson et al., 2002). In this modified version, the sub-categories for 'palustrine' systems were changed (to 'inflow', 'outflow', 'throughflow - channelled', and 'throughflow - unchannelled'), in an attempt to link in with the hydrological components at sub-system level for 'marine', 'estuarine', 'riverine' and 'lacustrine' systems.

Endorheic pans (i.e. shallow, inward-draining depressions) posed a major difficulty in adapting the system of Cowardin et al. (1979) for South Africa. The various draft national classification systems (e.g. Cowan and Van Riet, 1998; Dini et al., 1998;
Dini and Cowan, 2000; Thompson et al., 2002) dealt with these inland systems in different ways but at the heart of the problem was that the Cowardin system cannot explicitly distinguish endorheic pans from other 'lacustrine' and 'palustrine' wetlands, even if hydrogeomorphic sub-categories are introduced, due in no small part to a heavy reliance on structural distinctions at the primary level. This prompted the move towards a more fundamentally HGM-based approach to the classification of inland aquatic ecosystems, especially for wetlands.

\section{Hydrogeomorphically based classification systems in South Africa}

In South Africa in recent years, the use of HGM-based classification systems has become widespread, especially for wetland inventories, wetland assessment, and conservation planning initiatives for freshwater ecosystems. A summary of how the classification of HGM Units for wetlands and other inland aquatic ecosystems in South Africa has been dealt with by nationally-applicable classification systems developed to date is provided in Table 1.

One of the first attempts at introducing an HGM approach to wetland classification was that of Kotze et al. (1994). Kotze and colleagues described different wetland types firstly by identifying the terrain unit in which a wetland was located (using typical terminology of soil scientists) and then categorising the landform of the wetland. In the years that followed, this classification system was modified by merging various combinations of terrain unit and landform into a single-level classification (Kotze, 1999).The more recently developed techniques for the assessment of the ecological condition of wetlands (WETHealth: Macfarlane et al., 2008; Kotze et al., 2012) and the

\begin{tabular}{|c|c|c|c|c|c|c|}
\hline \multicolumn{7}{|c|}{$\begin{array}{l}\text { TABLE } 1 \\
\text { Classification of HGM Units for wetlands and other inland aquatic ecosystems in South Africa by nationally-applicable } \\
\text { classification systems developed to date }\end{array}$} \\
\hline Kotze et al. (1994) & Kotze (1999) & $\begin{array}{l}\text { Kotze et } \\
\text { al. (2008); } \\
\text { Macfarlane et al. } \\
(2008)\end{array}$ & $\begin{array}{l}\text { Sieben et al. } \\
(2011)\end{array}$ & $\begin{array}{l}\text { Rountree and } \\
\text { Batchelor (DWAF, } \\
\text { 2007b) }\end{array}$ & $\begin{array}{l}\text { Ewart-Smith et al. } \\
(2006)\end{array}$ & Ollis et al. (2009a) \\
\hline $\begin{array}{l}\text { Crest/Scarp/ } \\
\text { Midslope/ } \\
\text { Footslope/Valley } \\
\text { head/Young valley } \\
\text { bottom/Mature } \\
\text { valley bottom: } \\
\text { - Flat } \\
\text { - Depression } \\
\text { - Channel } \\
\text { - Slope } \\
\text { - Fringe } \\
\text { - Channelled flat } \\
\text { - Channel- } \\
\text { disrupting flat }\end{array}$ & $\begin{array}{l}\text { - Channel } \\
\text { - Channelled val- } \\
\text { ley bottom } \\
\text { - Non-channelled } \\
\text { valley bottom } \\
\text { - Hill slope } \\
\text { - Flow concentra- } \\
\text { tion area } \\
\text { - Depression }\end{array}$ & $\begin{array}{l}\text { - Floodplain } \\
\text { - Valley bottom, } \\
\text { channelled } \\
\text { - Valley bottom, } \\
\text { unchannelled } \\
\text { - Hillslope seep- } \\
\text { age linked to a } \\
\text { stream } \\
\text { - Isolated } \\
\text { hillslope } \\
\text { seepage } \\
\text { - Depression } \\
\text { (incl. Pans) }\end{array}$ & $\begin{array}{l}\text { - Floodplain } \\
\text { - Valley bottom } \\
\text { with a channel } \\
\text { - Valley bot- } \\
\text { tom without a } \\
\text { channel } \\
\text { - Hillslope seep- } \\
\text { age feeding a } \\
\text { stream } \\
\text { - Hillslope seep- } \\
\text { age not feeding } \\
\text { a stream } \\
\text { - Depression/Pan } \\
\text { - River margin } \\
\text { and veg- } \\
\text { etated channel } \\
\text { deposits } \\
\text { - Flat/ } \\
\text { Groundwater } \\
\text { rest-level } \\
\text { wetland } \\
\text { - Isolated spring } \\
\text { - Dolomite cave } \\
\text { - Raised bog } \\
\text { - Geothermal } \\
\text { spring }\end{array}$ & $\begin{array}{l}\text { Valley bottoms: } \\
\text { - River } \\
\text { - Lake } \\
\text { - Unchannelled } \\
\text { valley bottom } \\
\text { - Channelled val- } \\
\text { ley bottom } \\
\text { - Meandering } \\
\text { floodplain } \\
\text { Slopes: } \\
\text { - Seepage } \\
\text { (isolated) } \\
\text { - Seepage } \\
\text { (connected) } \\
\text { Crests: } \\
\text { - Seepage } \\
\text { (connected) } \\
\text { - Pans and } \\
\text { depressions' }\end{array}$ & $\begin{array}{l}\text { Non-isolated: } \\
\text { - Channel (river) } \\
\text { - Valley bottom } \\
\text { - Floodplain } \\
\text { - Depression } \\
\text { linked to a } \\
\text { channel } \\
\text { - Seep with chan- } \\
\text { nelled outflow } \\
\text { Isolated: } \\
\text { - Isolated } \\
\text { depression } \\
\text { - Seep without } \\
\text { channelled } \\
\text { outflow }\end{array}$ & $\begin{array}{l}\text { Valley floor/Slope/ } \\
\text { Plain/Bench: } \\
\text { - Channel (river) } \\
\text { - Channelled } \\
\text { valley-bottom } \\
\text { wetland } \\
\text { - Unchannelled } \\
\text { valley-bottom } \\
\text { wetland } \\
\text { - Floodplain } \\
\text { wetland } \\
\text { - Hillslope seep } \\
\text { - Valleyhead seep } \\
\text { - Depression } \\
\text { - Flat }\end{array}$ \\
\hline
\end{tabular}


ecosystem services provided by wetlands (WET-EcoServices: Kotze et al., 2008) were fundamentally based on the HGM approach to wetland classification. These techniques, which were specifically designed for palustrine (i.e. vegetated) inland wetlands, make use of 6 HGM units (adapted from Kotze, 1999 - see Table 1), defined on the basis of geomorphic setting, water source and how water flows through a wetland unit.

As part of a proposed framework for wetland rehabilitation planning in South Africa, Sieben et al. (2011) have expanded the HGM-based classification system of Kotze et al. (2008) and Macfarlane et al. (2008) to include 7 additional HGM units (Table 1). Sieben et al. (2011) also present a list of discriminators for distinguishing between different habitat types within an HGM unit, at a lower (more detailed) level of classification.

The development of a nationally applicable classification system for inland aquatic ecosystems has been pursued by Mark Rountree and the late Allan Batchelor on behalf of the South African Department of Water Affairs (DWA, now the Department of Water and Sanitation). This system is also based on the HGM approach but has a broader scope than the system used for WET-EcoServices (Kotze et al., 2008) and WET-Health (Macfarlane et al., 2008), in that it considers 'rivers' and 'lakes' (including impoundments) as well as wetlands. The proposed wetland types are similar to those of the classification system developed for WET-Health and WET-EcoServices (Table 1). This classification system is still under development and the only formal documentation available to date is that presented as an appendix to DWAF (2007b).

The HGM-based classification system presented in a draft version of WET-EcoServices was used to inform the designation of HGM units for inland wetlands in the development of a preliminary classification system for the National Wetland Inventory (Ewart-Smith et al., 2006). Unlike the WETEcoServices/WET-Health classification system, however, the preliminary classification system presented by Ewart-Smith et al. (2006) was hierarchical in nature, and took into account all inland systems (including rivers and open waterbodies, in addition to wetlands), estuarine systems, and shallow marine systems. These aspects were retained in further revisions of the classification system (Ollis et al., 2009a, 2013).

A novel feature of the preliminary version of the classification system (as presented in Ewart-Smith et al., 2006) was the distinction that it made between 'isolated' and 'non-isolated' inland systems (at Level 2) on the basis of the presence or absence of an observable hydrological connection to a surface drainage network. This upfront distinction was, however, excluded from the later revision (Ollis et al., 2009a), partly because of the practical difficulty of consistently separating, at a high level of the classification system, inland aquatic ecosystems into two separate categories based on a link to the drainage network, when, in reality, one is often faced with a continuum of connectedness with the drainage network. There were also varied opinions amongst wetland and aquatic scientists as to what criteria should be used to distinguish between 'isolated' and 'non-isolated' systems. In addition to making it easier to apply, this change made the primary HGM types for inland systems of the revised versions of the classification system more directly comparable with those of the HGM-based classification systems independently developed for WET-Health (Macfarlane et al., 2008) and WET-EcoServices (Kotze et al., 2008), and for DWA (as presented in DWAF, 2007b).

The classification system described in the current paper, which is a further revision of the system presented by Ollis et al. (2009a), represents an attempt to bring about consistency in the terminology used for HGM-based classification of inland aquatic ecosystems across the country. Only the inland component of the classification system is discussed in detail because the marine and estuarine components are likely to be revised in the near future, following the advances made in the classification of these aquatic ecosystems through the marine (Sink et al., 2012) and estuarine (Van Niekerk and Turpie, 2012) components of the recently completed National Biodiversity Assessment 2011 (Driver et al., 2012).

\section{APPROACH TAKEN TO THE DEVELOPMENT OF A CLASSIFICATION SYSTEM FOR WETLANDS AND OTHER AQUATIC ECOSYSTEMS IN SOUTH AFRICA}

The classification system presented in the current paper was developed in a series of phases over a period of approximately 8 years, starting in 2005 with a project initiated by the South African National Biodiversity Institute (SANBI) and the Water Research Commission (WRC) to develop a preliminary classification system for application to the National Wetland Inventory.

This classification system is the result of a collaborative research effort between a number of aquatic/wetland scientists from different regions of the country, representing various institutions. Extensive input was obtained from aquatic/wetland scientists and managers across the country, through oneon-one consultations, the holding of a number of workshops, feedback at appropriate national conferences/meetings, and external peer-review of documentation that was produced. One of the key informants in the development of the classification system was a literature review on the classification of wetlands and aquatic ecosystems internationally and in South Africa (Ollis and Ewart-Smith, 2006); the review for South Africa is summarised earlier in this paper.

Various versions of the classification system have been tested. For the marine and estuarine components, the testing was undertaken at desktop level by marine (Clark, 2008) and estuarine (Turpie et al., 2008) specialists. For inland systems, testing was undertaken through both desktop- and fieldbased studies by relevant specialists. This testing involved the application of a particular version of the classification system to numerous aquatic ecosystems within a defined geographical region (i.e. at a broad spatial scale, mostly in the Western Cape) and to at least 20 specific case-study examples at a much finer spatial scale, as detailed in Ollis et al. (2009b). To ensure that the case-study based testing was undertaken across a wide range of geographical regions, the country was divided into 13 'ecoregion clusters' by grouping DWA's Level I Ecoregions (after Kleynhans et al., 2005) into clusters with similar broad-scale attributes, and at least one case-study example was selected from each 'ecoregion cluster'.

Key aspects evaluated during the testing were: (i) whether the classification system is robust enough to avoid the possibility of classifying particular aquatic ecosystem types in more than one way (i.e. the test of mutual exclusivity), and (ii) whether the classification system is comprehensive enough to capture the different types of aquatic ecosystems that occur and their characteristic features, while at the same time being as simple as possible for potential users to understand and apply.

Cursory testing of the consistency in the classification of aquatic ecosystems between different users of the classification system was also conducted. The version of the classification system presented in Ollis et al. (2009a) was independently applied to 7 case-study wetlands by 4 wetland specialists who did not 
have any knowledge of the systems, using only Google Earth imagery of the wetland and a portion of the relevant 1:50 000 scale topocadastral map (with additional photographs provided in two of the cases). The classification system was applied up to the level of HGM Units in this desktop-based exercise.

\section{Summarised results of the application and testing of the proposed classification system}

The desktop-based case studies for inland systems showed a moderate degree of consistency in the classification of the landscape setting and HGM Units by 4 different 'classifiers'. This exercise did, however, highlight the fact that classification of the landscape setting of inland aquatic ecosystems would be more consistent if based on the use of geographic information systems (GIS) and a digital elevation model of suitable resolution. Furthermore, it was predicted that the provision of more detailed information (e.g. high-resolution aerial photographs, with fine-scale contour maps overlaid) would have improved the consistency and confidence with which HGM Units were classified. The gradient of the area within which an inland aquatic ecosystem is located was found to be particularly important in being able to apply both Levels 3 and 4 of the classification system confidently at desktop level. Overall, it was concluded that, if sufficiently detailed information is available and the definitions associated with the classification system are adhered to, it should be possible to apply the classification system at desktop level up to Level 4A (primary HGM Units) with a relatively high degree of consistency and accuracy (Ollis et al., 2009b). The best way to complete the desktop-based classification of HGM Units is to approach it on a catchment-by-catchment basis and, preferably, to include some field-based groundtruthing to calibrate the classification results.

The field-based application of various revisions of the proposed classification system to a number of case study wetlands from around the country highlighted a number of areas of potential confusion or difficulty, particularly for the lower levels of classification. These potential problem areas were used to refine the classification system. The main changes included refinement of definitions, simplification of the structure of the classification system (particularly at the lower levels), and clarification of the 'rules' for application of the system (Ollis et al., 2009a). By the end of the testing period, the project team was fairly confident that the classification system could be applied to most of the case-study wetlands with a relatively high degree of consistency, accuracy and ease (Ollis et al., 2009b).

Throughout the testing phases, the importance of recording the confidence with which categories were selected was continually highlighted.

Subsequent to the completion of the reports on the application, testing and further development of the classification system (Ollis et al., 2009a, b), significant progress has been made in the automated classification of wetlands and other inland aquatic ecosystems into HGM types at regional and national scales using GIS modelling techniques. For example, an earlier version of the classification system described in the current paper was applied in an automated manner to classify inland aquatic ecosystems for the National Wetland Map (available as an interactive map on SANBI's Biodiversity GIS website at http://bgis.sanbi.org), and for the wetland components of the NFEPA project (Driver et al., 2011; Nel et al. 2011a, b) and the 2011 National Biodiversity Assessment (Driver et al., 2012; Nel and Driver 2012).

\section{DESCRIPTION AND DISCUSSION OF THE PROPOSED CLASSIFICATION SYSTEM}

\section{Purpose of the classification system}

One of the main reasons for developing the proposed classification system was to provide a common language and consistent terminology that can be used for inland aquatic ecosystems throughout South Africa, and which caters specifically for the different types of wetlands that occur. It is envisaged that the classification system could be used for a range of different purposes and be applied at a variety of spatial scales. This has been facilitated by the development of a tiered (hierarchical) classification structure, with increasing amounts of detail provided at each successive level (as explained below) The more information that is available about an aquatic ecosystem, the more refined the classification can be of the type of aquatic ecosystem, and the greater the degree of confidence in the classification. The usefulness of the classification system is thus, ultimately, constrained by the type and extent of information available for the aquatic ecosystems that one wishes to apply the classification system to. Potential uses include, inter alia, wetland inventories (at national, regional and local scales), conservation planning initiatives for inland aquatic ecosystems, wetland and river rehabilitation planning, assessments of wetland and river health, assessments of wetland aquatic ecosystem service provision, water resource planning and management (e.g. application to ecological Reserve determinations), and design of wetland and river monitoring programmes. In addition to developing the classification system in such a way as to promote multiple uses, an attempt has been made to keep the classification system as simple and flexible as possible, without losing scientific rigour, so that it can be understood and utilised by a wide range of potential user-groups.

\section{Basic structure of the classification system}

The classification system is six-tiered in structure (Fig. 1). The first four levels distinguish between different types of aquatic ecosystems on the basis of 'primary discriminators', which are criteria that consistently differentiate between the specified categories at a particular level. The tiered structure progresses from 'Systems' (Marine vs. Estuarine vs. Inland) at the broadest spatial scale (Level 1), through to HGM Units (Level 4) as the core units of classification. 'Secondary discriminators' are applied at Level 5 to classify the tidal/hydrological regime of an HGM Unit, and 'Descriptors' at Level 6 to categorise a range of biophysical attributes. Certain categories within the classification system can be split on the basis of additional criteria; in these cases, the relevant tier is divided into sub-levels that are labelled with sequential letters of the alphabet (e.g. Level 3A and 3B; Level $4 \mathrm{~A}$ to $4 \mathrm{C}$, etc.).

The tiered structure of the classification system allows for the classification of an aquatic ecosystem up to a particular level, depending on the information available and the purpose of the classification. In most cases, provided sufficiently detailed data are available (in the form of maps, aerial photographs, satellite imagery and potentially relevant GIS layers, inter alia), it should be possible to classify an aquatic ecosystem to Level 4A (primary HGM Unit), or at least Level 3 (Subsystem / Landscape Unit), with a moderate degree of confidence. Detailed, field-based information would generally be required to classify HGM Units (at Level 4) with a high degree of confidence, and to classify an aquatic ecosystem to Level 5 (Tidal 


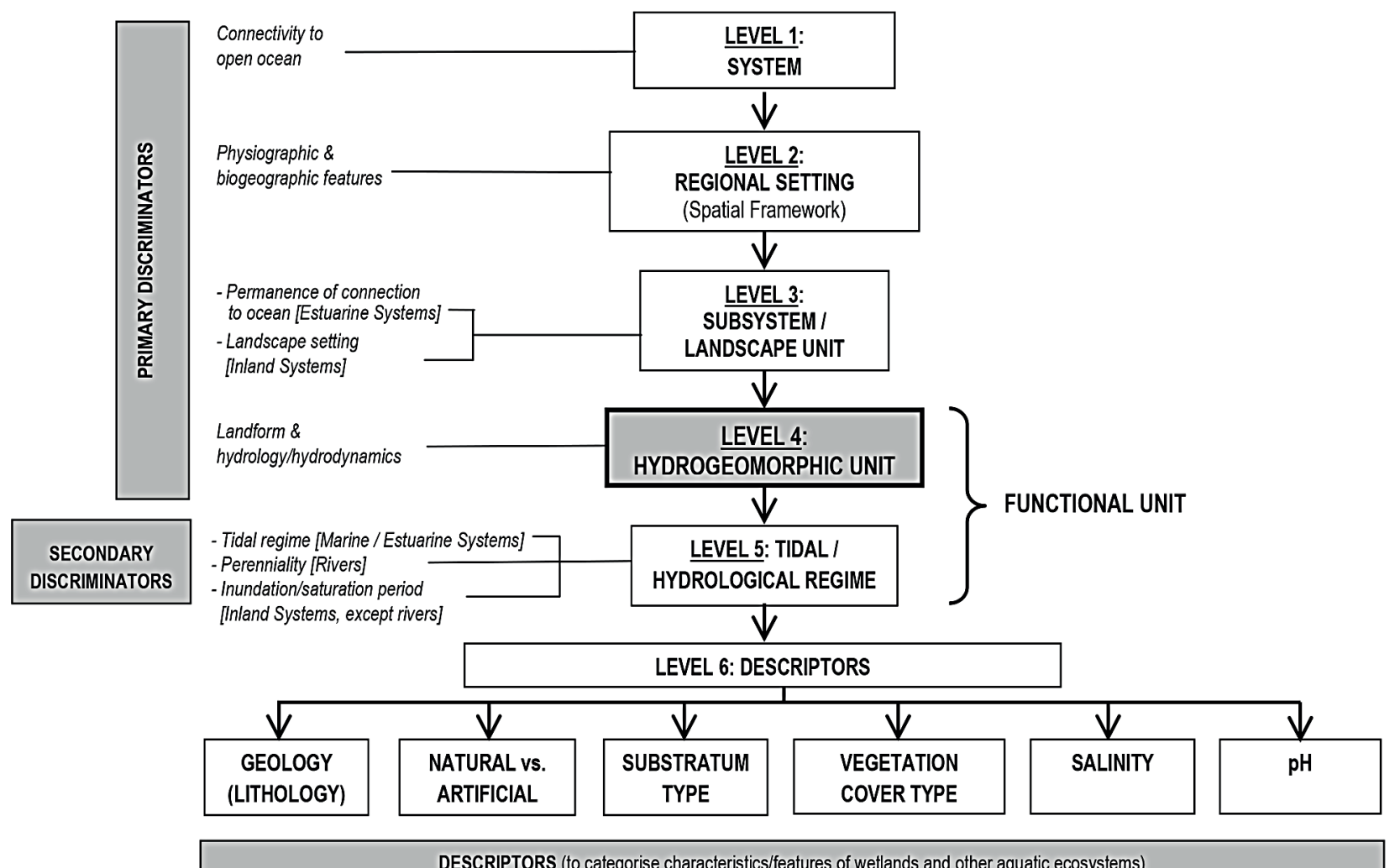

Figure 1

Conceptual overview of the classification system for wetlands and other aquatic ecosystems, showing how 'primary discriminators' are applied up to Level 4 to classify Hydrogeomorphic (HGM) Units, with 'secondary discriminators' applied at Level 5 to classify the Tidal/Hydrological Regime, and Descriptors applied at Level 6 to categorise the characteristics of aquatic ecosystems classified up to Level 5

Regime / Hydroperiod) and Level 6 (Descriptors) with a moderate to high degree of confidence.

At the System level (i.e. Level 1), a distinction is made between marine, estuarine and inland aquatic ecosystems using the degree of connectivity to the open ocean as the key discriminator. Inland Systems are characterised by the complete absence of marine exchange and/or tidal influence. Marine Systems, in contrast, are part of the open ocean, while Estuarine Systems are not themselves part of the ocean but are permanently or periodically open to the sea. Most rivers (a type of inland system) are indirectly connected to the ocean via an estuary at the downstream end. Where marine exchange (i.e. the presence of seawater) or tidal fluctuations are detectable in a river channel that is permanently or periodically connected to the ocean, that portion of the river is defined as part of the Estuarine System.

The HGM Unit at Level 4 and the Tidal Regime (for marine and estuarine systems) or the Hydrological Regime (for inland systems) at Level 5 of the classification system together constitute a Functional Unit (Fig. 1). This term is used to highlight the fact that the functioning of an aquatic ecosystem is determined primarily by the hydrogeomorphic characteristics (taken into account in the designation of HGM Units) and the tidal/ hydrological regime of the ecosystem. The HGM Unit, together with the Tidal/Hydrological Regime if this is known, is thus the focal point of the classification system. Levels 2 and 3 provide the broad biogeographical and landscape context for grouping HGM or Functional Units, while the Descriptors at Level 6 provide more detailed descriptions.

The classification of marine and estuarine systems is not dealt with further in the current paper. The descriptions of the components of the classification system that relate to inland aquatic ecosystems are complemented with references to a worked example, at least for Levels 2 to 5 . The worked example, which was one of the case studies for the field-based testing that was undertaken, is the Langvlei wetland system located near the town of Leliefontein in the Kamiesberg Uplands, Northern Cape Province (Fig. 2).

\section{Level 2: Regional Setting}

Regional variations in climate, geology, soils and vegetation are important in the development of different types of aquatic ecosystems. Consequently, there is a need to recognise regional differences when classifying inland aquatic ecosystems. This is usually achieved by using an existing spatial framework, or developing a new one, for the application of a classification system. Spatial frameworks are simply broad-scale (nationalto regional-level) maps that divide large areas into relatively homogenous units to provide a context for ecosystem management. At Level 2 of the classification system, Inland Systems are grouped on the basis of DWA Ecoregions (after Kleynhans et al., 2005) or the 'WetVeg Groups' of the National Freshwater Ecosystem Priority Areas (NFEPA) project (after Nel et al. (2011a). The NFEPA WetVeg Groups were derived by splitting the Bioregions of Rutherford et al. (2006) into 133 smaller groups based on input from wetland botanists and ecologists. Alternatively, instead of using DWA Ecoregions or NFEPA WetVeg Groups, any other spatial framework that is deemed to be appropriate for the particular application can be applied at Level 2 (Table 2, column 2). It is anticipated that the flexibility 


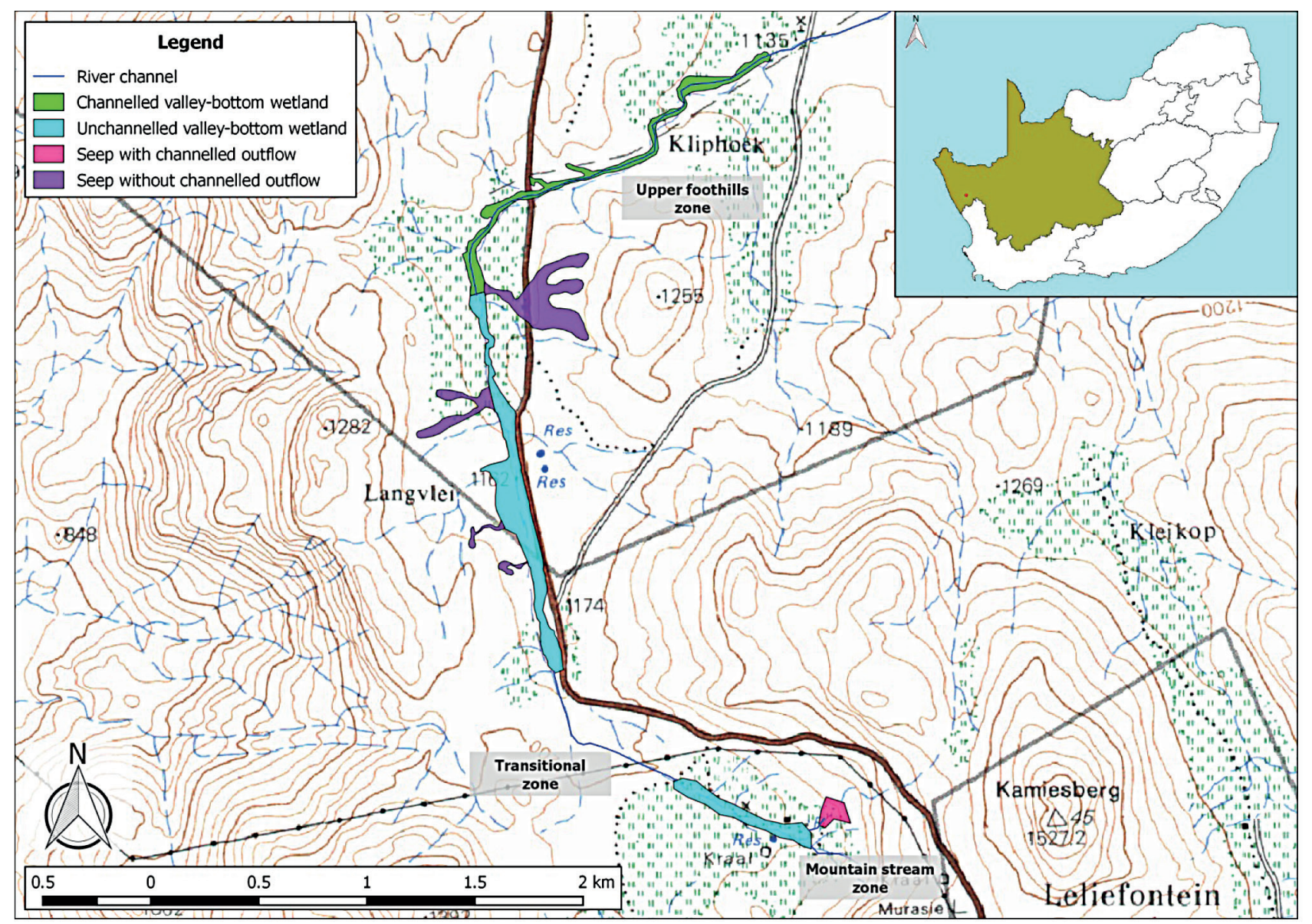

Figure 2

Map of primary HGM Units making up the Langvlei wetland system (inset map shows location of Langvlei as a red dot within the Northern Cape Province of South Africa)

introduced by providing options at this level will facilitate the use of the classification system for a variety of purposes.

With reference to the worked example, the Langvlei wetland is located within the Namaqua Highlands Ecoregion (after Kleynhans et al., 2005). Closed hills and mountains with moderate to high relief are distinctive of this Ecoregion, which is also characterised by a moderately high mean annual temperature, winter rainfall, a predominantly arid mean annual precipitation $(0-200 \mathrm{~mm})$, a high to very high coefficient of variation for annual precipitation, and a low to very low median annual simulated runoff (Kleynhans et al., 2005). This contextual information is valuable for understanding the characteristics of aquatic ecosystems in the region, including the Langvlei system. The categorisation of the NFEPA WetVeg Group, as Namaqualand Cape Shrublands Granite Renosterveld (after Nel et al., 2011), provides further information about the geology, soils and vegetation types that one can expect to find in and around the Langvlei wetland system.

\section{Level 3: Landscape Units}

One of the most significant changes made to the 'Inland' component of the classification system, in comparison to the original version of Ewart-Smith et al. (2006), besides doing away with the upfront distinction between 'isolated' and 'nonisolated' sub-systems, was the inclusion of the Landscape Unit to categorise the landscape setting of an aquatic ecosystem.
The Landscape Unit (at Level 3), together with the Regional Setting (at Level 2), provides an indication of the context within which an inland aquatic ecosystem occurs. In particular, the categorisation of the landscape setting provides a topographic context for each HGM Unit, which is potentially important because of the strong influence that the topographical position of an Inland System can have over the hydrological and hydrodynamic processes acting within the ecosystem and the related geomorphological processes.

A distinction is made between four primary Landscape Units (at Level 3A) on the basis of the broad-scale topographic features, defined as follows (Table 2, column 3):

- Valley Floor: the base of a valley, situated between two distinct valley side-slopes, where alluvial or fluvial processes typically dominate. The key factor that determines whether an Inland System is located on a valley floor is the presence of valley side-slopes within approximately $500 \mathrm{~m}$ of an aquatic ecosystem.

- Slope: an inclined stretch of ground typically located on the side of a mountain, hill or valley, not forming part of a valley floor. As a guideline, for purposes of the classification system, the gradient of a slope is taken to be typically $\geq 0.01$.

- Plain: an extensive area of low relief (generally $>50$ ha in extent). These areas are generally characterised by relatively level, gently undulating or uniformly sloping land with a very gentle gradient (typically $<0.01$ ) that is not located within a valley. Includes coastal plains, interior plains and plateaus. 
- Bench: a relatively discrete area of mostly level or nearly level high ground, relative to the broad surroundings (typically $<50$ ha in extent).

At Level 3B (Table 1, Column 4), a further distinction is made between three different types of benches, namely Hilltop, Saddle and Shelf (Fig. 3). Definitions are provided in the user manual for the classification system (Ollis et al., 2013).

Unlike broad-scale landscape features, the localised landscape setting is expected to directly influence the form and function of an Inland System. The categorisation of the Landscape Unit at Level 3 should therefore be considered at the same scale as the inland aquatic ecosystem that is being classified. This categorisation can assist in the identification of HGM Units (at Level 4) because certain HGM Units are typically associated with particular landscape settings (e.g. Seeps typically occur on Slopes and Valley-Bottom Wetlands typically occur along Valley Floors). The inclusion of Landscape Units should also assist greatly in facilitating the desktop automation of the classification system, which is especially important for national- and regional-scale initiatives.

In the case of the worked example, through an examination of $20 \mathrm{~m}$ interval contour lines (Fig. 2) and field observations, it was clear that the main part of the Langvlei wetland system and the main-stem river channel associated with this wetland are located along a Valley Floor, while the smaller wetlands draining in from the side are located on Slopes (as categorised at Level 3A of the classification system). This assisted with the identification of the HGM Units at Level 4, and in gaining a broad understanding of the flow of water into and through the Langvlei system.

\section{Level 4: Hydrogeomorphic Units}

Level 4 identifies HGM Units, defined primarily according to landform, hydrological characteristics, and hydrodynamics. Together, these factors affect the geomorphological and biogeochemical processes acting within an inland aquatic ecosystem. The primary HGM Units, as distinguished at Level $4 \mathrm{~A}$ and referred to as 'HGM Types', are the focal point of the classification system. Seven HGM Types are recognised for Inland Systems at Level 4A (Table 3, column 1):

- River: a linear landform with clearly discernable bed and banks, which permanently or periodically carries a concentrated flow of water. A river is taken to include both the active channel and the riparian zone as a unit. Concentrated, unidirectional flow within a distinct active channel, either permanently or periodically, is characteristic.
- Floodplain Wetland: a wetland area on the mostly flat or gently-sloping land adjacent to and formed by an alluvial river channel, under its present climate and sediment load, which is subject to periodic inundation by overtopping of the channel bank. Floodplain wetlands generally occur on a Plain and are typically characterised by a suite of geomorphological features associated with river-derived depositional processes.

- Channelled Valley-Bottom Wetland: a mostly flat wetland area located along a valley floor with a river channel running through it. Characterised by being positioned on a Valley Floor and the absence of characteristic floodplain features. Dominant water inputs are from the river channel flowing through the wetland, either as surface flow resulting from flooding or as lateral seepage, and/or from adjacent valley-side slopes.

- Unchannelled Valley-Bottom Wetland: a mostly flat wetland area located along a valley floor without a river channel running through it. Characterised by being positioned on a Valley Floor, an absence of distinct channel banks, and the prevalence of diffuse flows. Water inputs are typically from an upstream channel and seepage from adjacent valley side-slopes, as illustrated by the main Unchannelled ValleyBottom Wetland making up a large portion of the Langvlei wetland system (Fig. 2).

- Depression: an inland aquatic ecosystem with closed (or near-closed) elevation contours, which increases in depth from the perimeter to a central area of greatest depth, and within which water typically accumulates. May be flatbottomed (in which case they are often referred to as 'pans')

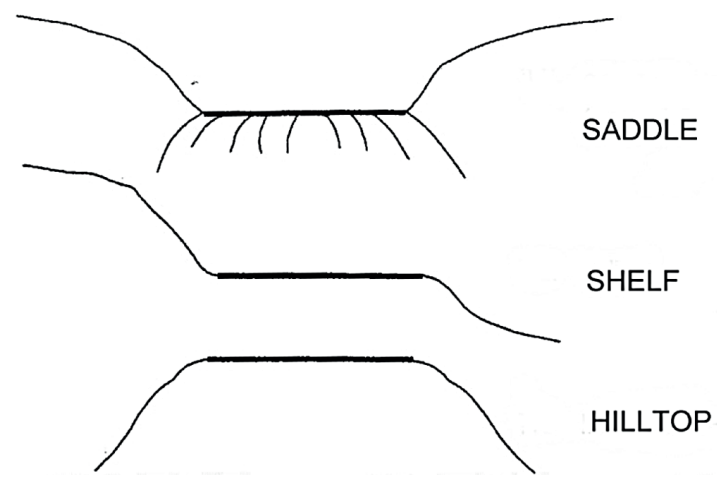

Figure 3

Schematic illustration of the three different types of bench settings for inland aquatic ecosystems (adapted from Longmore, 2001)

\begin{tabular}{|c|c|c|c|}
\hline \multicolumn{4}{|c|}{$\begin{array}{l}\text { TABLE } 2 \\
\text { Classification structure for inland aquatic ecosystems, up to Level } 3\end{array}$} \\
\hline LEVEL 1: SYSTEM & LEVEL 2: REGIONAL SETTING & \multicolumn{2}{|c|}{ LEVEL 3: LANDSCAPE UNIT } \\
\hline \multirow{2}{*}{ Connectivity to open ocean } & \multirow{2}{*}{ Spatial framework } & \multicolumn{2}{|c|}{ Landscape setting } \\
\hline & & A & B \\
\hline \multirow{6}{*}{ INLAND } & \multirow{6}{*}{$\begin{array}{l}\text { DWA Level I Ecoregions } \\
\qquad \text { OR } \\
\text { NFEPA WetVeg Groups } \\
\text { OR } \\
\text { Other spatial framework }\end{array}$} & Slope & $\mathrm{n} / \mathrm{a}$ \\
\hline & & Valley Floor & $\mathrm{n} / \mathrm{a}$ \\
\hline & & Plain & $\mathrm{n} / \mathrm{a}$ \\
\hline & & \multirow{3}{*}{ Bench } & Hilltop \\
\hline & & & Saddle \\
\hline & & & Shelf \\
\hline
\end{tabular}


or round-bottomed, and may have any combination of inlets and outlets or lack them completely. Variety of potential sources of water input but hydrodynamics are typically dominated by (primarily seasonal) vertical fluctuations. For purposes of the classification system, natural lakes (including coastal lakes) and dams (i.e. artificial lakes), which are typically drowned valley floors, are considered to be depressions.

- Seep: a wetland area located on gently to steeply sloping land and dominated by the colluvial (i.e. gravity-driven), unidirectional movement of water and material downslope. Water inputs are primarily via subsurface flows from an up-slope direction.

- Wetland Flat: a level or near-level wetland area that is not fed by water from a river channel, and which is typically situated on a Plain or a Bench. The primary source of water is generally precipitation, with the exception of Wetland Flats situated on a coastal plain where groundwater may rise to or near the ground surface. Horizontal water movements within the wetland are typically weak and multidirectional, if present at all.

The depth of a permanently inundated depression, which is one of the most important criteria for distinguishing between lakes/reservoirs (limnetic ecosystems) and wetlands (littoral systems), is taken into account with the Hydrological Regime at Level 5C. Depth data are often not available, especially from desktop-based sources of information, which is why lakes and other limnetic depressions have not been separated from

\begin{tabular}{|c|c|c|}
\hline \multicolumn{3}{|c|}{$\begin{array}{c}\text { TABLE } 3 \\
\text { Hydrogeomorphic (HGM) Units for inland systems at Level } 4\end{array}$} \\
\hline \multicolumn{3}{|c|}{ LEVEL 4: HYDROGEOMORPHIC (HGM) UNIT } \\
\hline HGM Type & Longitudinal zonation/landform/outflow drainage & Landform/inflow drainage \\
\hline A & B & $\mathrm{C}$ \\
\hline \multirow{18}{*}{ River } & \multirow{2}{*}{ Mountain Headwater Stream } & Active Channel \\
\hline & & Riparian Zone \\
\hline & \multirow{2}{*}{ Mountain Stream } & Active Channel \\
\hline & & Riparian Zone \\
\hline & \multirow{2}{*}{ Transitional } & Active Channel \\
\hline & & Riparian Zone \\
\hline & \multirow{2}{*}{ Upper Foothills } & Active Channel \\
\hline & & Riparian Zone \\
\hline & \multirow{2}{*}{ Lower Foothills } & Active Channel \\
\hline & & Riparian Zone \\
\hline & \multirow{2}{*}{ Lowland River } & Active Channel \\
\hline & & Riparian Zone \\
\hline & \multirow{2}{*}{ Rejuvenated Bedrock Fall } & Active Channel \\
\hline & & Riparian Zone \\
\hline & \multirow{2}{*}{ Rejuvenated Foothills } & Active Channel \\
\hline & & Riparian Zone \\
\hline & \multirow{2}{*}{ Upland Floodplain } & Active Channel \\
\hline & & Riparian Zone \\
\hline \multirow{2}{*}{ Floodplain Wetland } & Floodplain Depression & $\mathrm{n} / \mathrm{a}$ \\
\hline & Floodplain Flat & $\mathrm{n} / \mathrm{a}$ \\
\hline Channelled Valley-Bottom Wetland & $\mathrm{n} / \mathrm{a}$ & $\mathrm{n} / \mathrm{a}$ \\
\hline Unchannelled Valley-Bottom Wetland & $\mathrm{n} / \mathrm{a}$ & $\mathrm{n} / \mathrm{a}$ \\
\hline \multirow{6}{*}{ Depression } & \multirow{2}{*}{ Exorheic } & With Channelled Inflow \\
\hline & & Without Channelled Inflow \\
\hline & \multirow{2}{*}{ Endorheic } & With Channelled Inflow \\
\hline & & Without Channelled Inflow \\
\hline & \multirow{2}{*}{ Dammed } & With Channelled Inflow \\
\hline & & Without Channelled Inflow \\
\hline \multirow{2}{*}{ Seep } & With Channelled Outflow & $\mathrm{n} / \mathrm{a}$ \\
\hline & Without Channelled Outflow & $\mathrm{n} / \mathrm{a}$ \\
\hline Wetland Flat & $\mathrm{n} / \mathrm{a}$ & $\mathrm{n} / \mathrm{a}$ \\
\hline
\end{tabular}


depression wetlands as distinct HGM Types at Level 4A. At Level 4B (Table 3, Column 2), Rivers and Floodplain Wetlands are further divided on the basis of longitudinal geomorphological zonation and localised landform, respectively. Rivers are divided into 9 longitudinal zones, according to the geomorphological zonation scheme of Rowntree and Wadeson (2000). Floodplains are complex landscapes supporting a variety of features (such as backwater depressions, meander cutoffs, alluvial ridges, levees, scroll bars, etc.). It is, however, often difficult to distinguish clearly between certain wetland features within a floodplain (e.g. meander cut-offs vs. backwater depressions), particularly in active floodplain wetlands within which there may be a continuum of younger and older features associated with channel migration. To cater for these complexities in the simplest way possible, Floodplain Wetlands are simply divided into Floodplain Depressions and Floodplain Flats.

Although the primary criteria for distinguishing a Floodplain Wetland from a Channelled Valley-Bottom Wetland (at Level 4A) are periodic flooding and the presence of particular geomorphological features, it may be difficult to ascertain whether these criteria have been met in certain situations, especially when conducting a desktop-based classification. In such situations, the longitudinal zonation of the river flowing through the wetland (as classified at Level 4B) can be used as a secondary criterion. As a guideline, wetland areas adjacent to river channels in the Lowland River or Upland Floodplain Zones (i.e. lowland rivers with gradients $<0.001$ and upland rivers with gradients $<0.005$ ) that are subject to periodic flooding should, by default, be classified as Floodplain Wetlands, whereas wetlands that are also subject to periodic inundation by overtopping of the channel bank but are located in longitudinal river zones with steeper gradients should be classified as Channelled Valley-Bottom Wetlands. The presence of visible floodplain features should take precedence, however. As a case in point, in the worked example of the Langvlei system (Fig. 2), the wetland located along the Valley Floor with a river channel running through it was classified as a Channelled ValleyBottom Wetland because the gradient of the river channel (forming part of the Upper Foothills Zone of the river) was steeper than 0.005 and there was an absence of typical meandering floodplain features within the wetland.

Depressions and Seeps can be classified further at Level 4B according to their outflow drainage characteristics. Depressions can be categorised as 'exorheic' (i.e. outward-draining), 'endorheic' (i.e. inward-draining), or 'dammed' (where the outflow drainage is regulated by the nature or operation of an artificial barrier). By definition, water leaves an Endorheic Depression by means of evaporation and infiltration only, whereas water can leave an Exorheic Depression as concentrated or diffuse surface flow, or as subsurface flow. Seeps are sub-divided into those 'with channelled outflow' and those 'without channelled outflow' at Level 4B. With reference to the worked example, both of these Seep sub-types were present along the valley sideslopes of the Langvlei wetland system (Fig. 2).

At Level 4C (Table 3, column 3), Rivers can be split into the 'active channel' and the 'riparian zone' based on landform characteristics, while Depressions can be classified further according to their inflow drainage characteristics into those 'with channelled inflow' and those 'without channelled inflow'. This latter distinction is very important for management purposes because the water quality and other characteristics of a Depression with channelled inflow will be directly related to those of the inflowing channel/s, which is not the case for Depressions with no channelled inflow. In the case of Rivers, it is necessary to distinguish between the active channel and the riparian zone (i.e. the area of land directly adjacent to the active channel, which is influenced by river-induced or riverrelated processes) if any of the Descriptors (at Level 6) are to be applied. If the area immediately adjacent to an active channel is subject to prolonged periods of inundation or saturation so that it qualifies as a wetland, this area should be classified as the relevant wetland HGM Type (i.e. a Floodplain or Channelled Valley-Bottom Wetland) and not as a riparian zone. For example, in the case of the Langvlei wetland system (Fig. 2), the area immediately adjacent to the active channel flowing through the northern portion of the wetland system was classified as a Channelled Valley-Bottom Wetland and not as a riparian zone.

Table 4 provides a summary of the seven HGM Types (i.e. the primary HGM Units recognised at Level 4A) and their dominant hydrological characteristics and hydrodynamics, together with an indication of the secondary HGM Units (as included at Level 4B) and typical landscape setting/s (at Level 3) associated with each HGM Type. Schematic diagrams of the HGM Types, illustrating their characteristic features, are provided in the user manual for the classification system (Ollis et al., 2013)

\section{Level 5: Hydrological Regime (and Inundation Depth-Class)}

The Hydrological Regime, which describes the behaviour of water within an aquatic ecosystem, directly affects the physi$\mathrm{cal}$, chemical and biological characteristics of an inland aquatic ecosystem (and its soils in the case of wetlands). The categorisation of the hydrological regime needs to be treated differently for Rivers than for other HGM Types because the flow regime (i.e. perenniality) is the major discriminator for the hydrological regime of Rivers, whereas the inundation and saturation period are the major discriminating factors for other HGM Types.

The primary flow regime categories that have been included for Rivers (at Level 5A) are 'perennial' and 'non-perennial', the latter being further divided into 'seasonal' and 'intermittent' flow types (at Level 5B):

- Perennial: flows continuously throughout the year, in most years.

- Non-perennial: does not flow continuously throughout the year, although pools may persist.

- Seasonal: water flows for extended periods during the wet season/s (generally between 3 to 9 months duration) but not during the rest of the year.

- Intermittent: water flows for a relatively short time of less than one season's duration (i.e. less than approximately 3 months), at intervals varying from less than a year to several years.

With reference to the worked example, all the rivers in the vicinity of the Langvlei wetland system are non-perennial due to the aridity of the region, with the main river associated with the wetland system being seasonal (as classified at Level 5B).

Four primary categories are provided at Level 5A for classifying the period of inundation associated with non-river inland aquatic ecosystems (Table 5, Column 1):

- Permanently Inundated: with surface water present throughout the year, in most years.

- Seasonally Inundated: with surface water present for extended periods during the wet season/s (generally between 3 to 9 months duration) but drying up annually, either to complete dryness or to saturation.

- Intermittently Inundated: holding surface water for irregular periods of less than one season (i.e. less than 


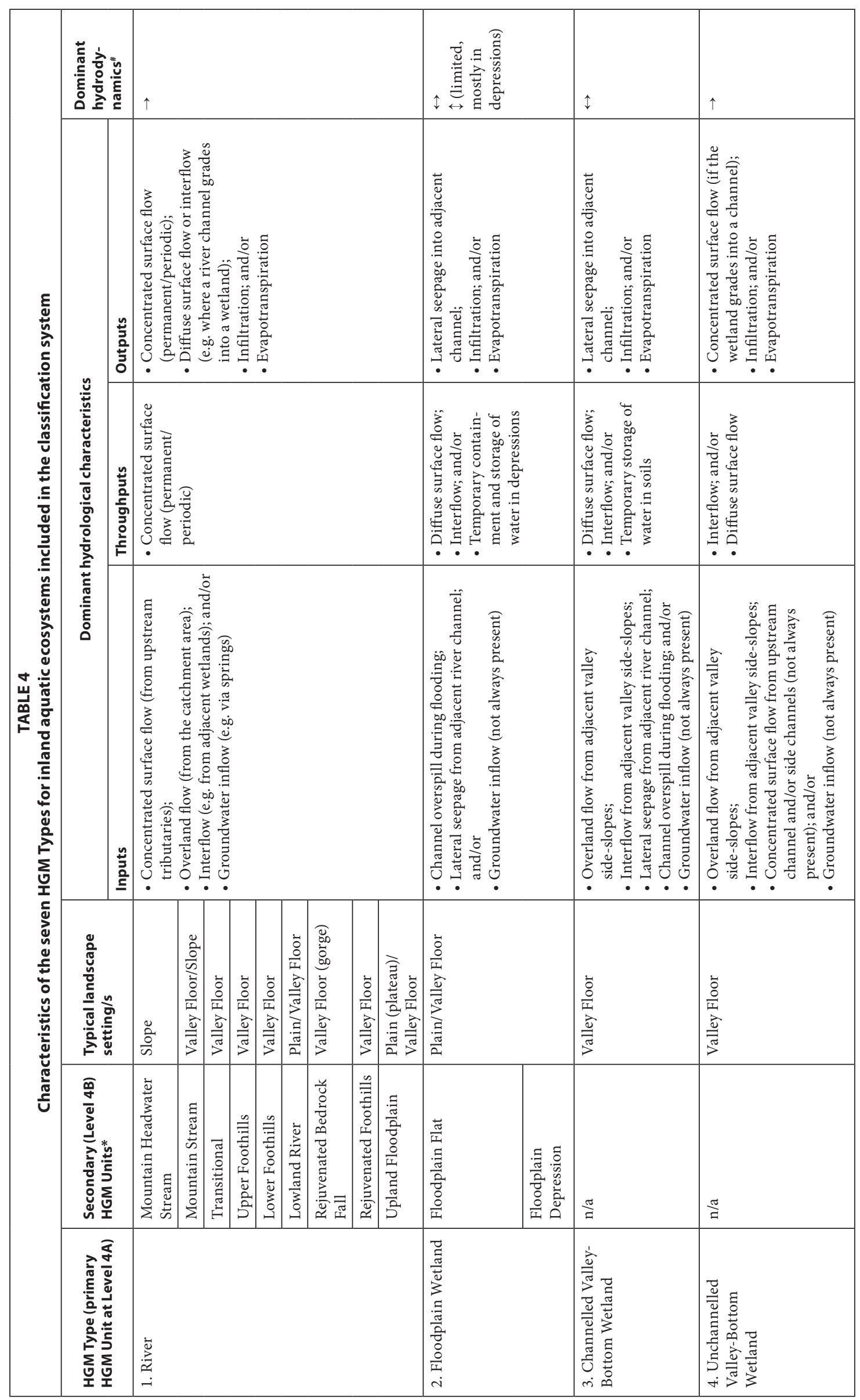




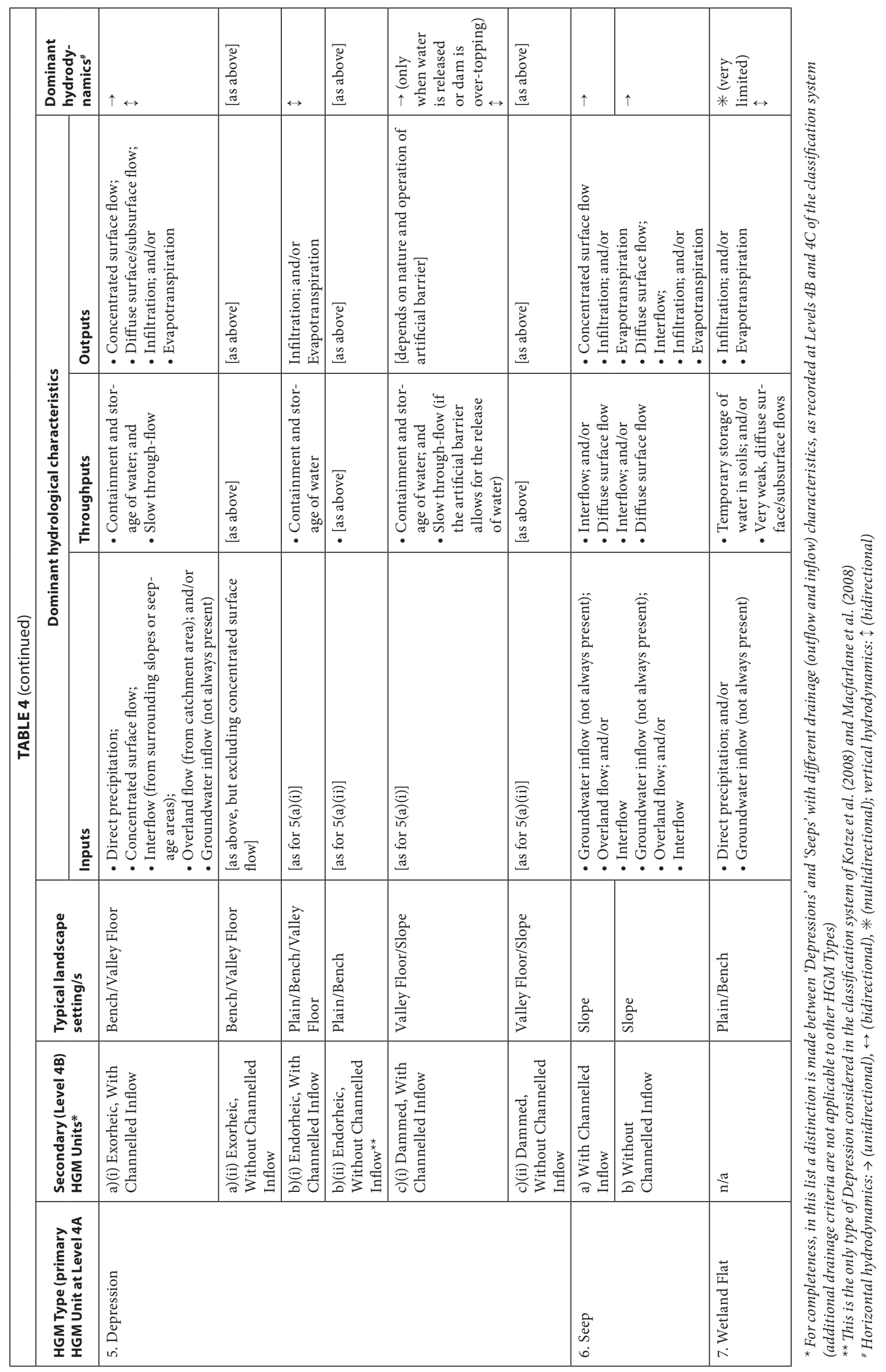


approximately 3 months), at intervals varying from less than a year to several years.

- Never/Rarely Inundated: covered by water for less than a few days at a time (up to a week at most), if ever.

At Level 5B, the saturation period within the upper $0.5 \mathrm{~m}$ of the soil surface is classified according to the following categories (Table 5, Column 2):

- Permanently Saturated: where all the spaces between the soil particles are filled with water throughout the year, in most years.

- Seasonally Saturated: with all the spaces between the particles filled with water for extended periods (generally between 3 to 9 months duration), usually during the wet season/s, but dry for the rest of the year.

- Intermittently Saturated: with all the spaces between the soil particles filled with water for irregular periods of less than one season (i.e. less than approximately 3 months), but remaining dry the rest of the time.

The period of saturation is considered for the upper $0.5 \mathrm{~m}$ of soil because this is usually the maximum depth to which soil saturation is investigated for wetland identification and delineation purposes (e.g. DWAF, 2005). In the case of the Langvlei wetland system (Fig. 2), the hydroperiod of the Valley-Bottom Wetlands could be described as mostly intermittently inundated (with portions being never/rarely inundated) and seasonally to intermittently saturated within the upper $0.5 \mathrm{~m}$ of the soil surface, as classified at Levels $5 \mathrm{~A}$ and $5 \mathrm{~B}$, respectively. The hydroperiod of most of the Seeps associated with this

\begin{tabular}{|c|c|c|}
\hline \multicolumn{3}{|c|}{$\begin{array}{c}\text { TABLE } 5 \\
\text { Hydroperiod and Inundation Depth-Class categories fo } \\
\text { Inland Systems other than Rivers, } \\
\text { at Level } 5 \text { of the classification system }\end{array}$} \\
\hline \multicolumn{3}{|c|}{ LEVEL 5: HYDROPERIOD AND DEPTH OF INUNDATION } \\
\hline A & B & c \\
\hline $\begin{array}{l}\text { Inundation } \\
\text { Period }\end{array}$ & $\begin{array}{l}\text { Saturation Period } \\
\text { (within } 0.5 \mathrm{~m} \text { of soil } \\
\text { surface) }\end{array}$ & $\begin{array}{l}\text { Inundation } \\
\text { Depth-Class }\end{array}$ \\
\hline \multirow{3}{*}{$\begin{array}{l}\text { Permanently } \\
\text { Inundated }\end{array}$} & \multirow{3}{*}{$\mathrm{n} / \mathrm{a}$} & Limnetic \\
\hline & & Littoral \\
\hline & & Unknown \\
\hline \multirow{3}{*}{$\begin{array}{l}\text { Seasonally } \\
\text { Inundated }\end{array}$} & Permanently Saturated & $\mathrm{n} / \mathrm{a}$ \\
\hline & Seasonally Saturated & $\mathrm{n} / \mathrm{a}$ \\
\hline & Unknown & $\mathrm{n} / \mathrm{a}$ \\
\hline \multirow{4}{*}{$\begin{array}{l}\text { Intermittently } \\
\text { Inundated }\end{array}$} & Permanently Saturated & $\mathrm{n} / \mathrm{a}$ \\
\hline & Seasonally Saturated & $\mathrm{n} / \mathrm{a}$ \\
\hline & Intermittently Saturated & $\mathrm{n} / \mathrm{a}$ \\
\hline & Unknown & $\mathrm{n} / \mathrm{a}$ \\
\hline \multirow{4}{*}{$\begin{array}{l}\text { Never/Rarely } \\
\text { Inundated }\end{array}$} & Permanently Saturated & $\mathrm{n} / \mathrm{a}$ \\
\hline & Seasonally Saturated & $\mathrm{n} / \mathrm{a}$ \\
\hline & Intermittently Saturated & $\mathrm{n} / \mathrm{a}$ \\
\hline & Unknown & $\mathrm{n} / \mathrm{a}$ \\
\hline \multirow{3}{*}{ Unknown } & Permanently Saturated & $\mathrm{n} / \mathrm{a}$ \\
\hline & Seasonally Saturated & $\mathrm{n} / \mathrm{a}$ \\
\hline & Intermittently Saturated & $\mathrm{n} / \mathrm{a}$ \\
\hline
\end{tabular}

wetland system could be categorised as never/rarely inundated (at Level 5A) and intermittently saturated (at Level 5B). The arid nature of the Langvlei wetland system is thus clearly brought out by the classification of the Hydrological Regime of the HGM Units making up this inland aquatic ecosystem.

Two depth classes are included at Level 5C to classify the maximum depth of inundation, specifically for permanently inundated Inland Systems (i.e. open waterbodies), namely 'limnetic' ( $\geq 2 \mathrm{~m}$ maximum depth at the average annual lowwater level) and 'littoral' ( $<2 \mathrm{~m}$ maximum depth at the average annual low-water level) (Table 4, column 3). This allows for the distinction between deepwater habitats (sensu Cowardin et al., 1979), where water (rather than air) is the principal medium within which the dominant organisms live, and more shallowly inundated areas where emergent vegetation tends to occur. A depth of $2 \mathrm{~m}$ has been used to separate limnetic from littoral units because this depth is usually considered to be the maximum depth at which rooted emergent macrophytes can grow (Cowardin et al., 1979).

A 6-point rating scale has been developed for use when assessing the relative proportions of each Hydroperiod category (at Levels 5A and 5B) within an Inland System (Table 6). Such a scale is not needed for Rivers because they are simply classified as either perennial or non-perennial and, if non-perennial, as seasonal or intermittent. The classification of the hydroperiod of a wetland or open waterbody is, however, more complicated because these ecosystems often don't have uniform patterns of wetness, spatially and/or temporally. Detailed explanation and a worked example of the application of the rating scale are given in the user manual (Ollis et al., 2013).

\section{LEVEL 6: DESCRIPTORS}

Six Descriptors are included for optional application at Level 6, to allow for detailed categorisation of the structural, chemical and/or biological characteristics of an HGM Unit:

These descriptors essentially provide a means of describing the habitat types within an HGM Unit and are similar to, but slightly less comprehensive than, the list of wetland habitat types presented by Sieben et al. (2011). A summary of the categories available for each of the descriptors is presented in Fig. 4. More detailed information about the Descriptor categories, including definitions and photographic examples, can be found in the user manual (Ollis et al., 2013).

Each HGM Unit may include more than one category of habitat type in terms of Descriptors such as substratum and vegetation cover type. The relative proportion of the categories for each descriptor can be rated according to aerial coverage, using the rating scale presented in Table 6 .

TABLE 6

Rating scale for categorisation of the Hydroperiod (at Levels 5A and 5B) and Descriptors (at Level 6)

\begin{tabular}{|l|l|l|}
\hline Rating & Range (\%) & Description \\
\hline 0 & $0 \%$ & Not present \\
\hline 1 & $>0-5 \%$ & Rare \\
\hline 2 & $>5-25 \%$ & Sparse \\
\hline 3 & $>25-50 \%$ & Common \\
\hline 4 & $>50-75 \%$ & Abundant \\
\hline 5 & $>75-95 \%$ & Predominant \\
\hline 6 & $>95-100 \%$ & Near-entire \\
\hline
\end{tabular}




\begin{tabular}{|l|l|}
\hline \multicolumn{2}{|c|}{ Natural vs. Artificial } \\
\hline Natural & Canal \\
\hline \multirow{5}{*}{ Artificial } & Dam (in-channel) \\
\hline & Dam (off-channel) \\
\hline & $\begin{array}{l}\text { Open reservoir } \\
\text { Excavation }\end{array}$ \\
\cline { 2 - 2 } & Salt works -- \\
\hline & WWTw pond \\
\hline & Aquaculture pond \\
\hline & Stormwater pond \\
\hline & Irrigated land \\
\hline & Other \\
\hline
\end{tabular}

\begin{tabular}{|c|c|c|}
\hline \multicolumn{3}{|c|}{ Salinity } \\
\hline & TDS & Conductivity \\
\hline Fresh & $<2 \mathrm{~g} / \mathrm{l}$ & $<\mathrm{ca} .300 \mathrm{mS} / \mathrm{m}$ \\
\hline Brackish & $2-12 \mathrm{~g} / \mathrm{I}$ & ca. $300-1800 \mathrm{~ms} / \mathrm{m}$ \\
\hline Saline & $12-40 \mathrm{~g} / \mathrm{l}$ & ca. $1800-6000 \mathrm{~ms} / \mathrm{m}$ \\
\hline Hypersaline & $>40 \mathrm{~g} / \mathrm{l}$ & $>$ ca. $6000 \mathrm{~ms} / \mathrm{m}$ \\
\hline
\end{tabular}

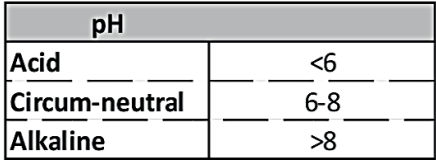

\begin{tabular}{|c|c|}
\hline \multicolumn{2}{|c|}{ Substratum type } \\
\hline Bedrock & \\
\hline Boulders & \\
\hline Cobbles & \\
\hline \multirow{2}{*}{ Pebbles/gravel } & Pebbles \\
\hline & $\overline{\text { Gravel }}$ \\
\hline \multirow{2}{*}{ Sandy soil } & Sand \\
\hline & Loamy sand \\
\hline \multicolumn{2}{|l|}{ Silt (mud) } \\
\hline \multirow{3}{*}{ Clayey soil } & Clay ___ \\
\hline & $\overline{\text { San }} d \bar{y}$ clay \\
\hline & Silty clay \\
\hline \multirow{6}{*}{ Loamy soil } & Loam \\
\hline & Sandy loam \\
\hline & Silt loam \\
\hline & Clay loam \\
\hline & Sandy clay loam \\
\hline & Silty clay loam \\
\hline \multirow{2}{*}{ Organic soil } & Peat \\
\hline & $\overline{<30 \%} \overline{\text { organic carbon }}$ \\
\hline \multicolumn{2}{|l|}{ Salt crust } \\
\hline Other & \\
\hline
\end{tabular}

\begin{tabular}{|c|c|c|c|c|}
\hline \multicolumn{5}{|c|}{ Vegetation cover } \\
\hline Unvegetated & & & & \\
\hline \multirow{16}{*}{ Vegetated } & \multirow{4}{*}{ Aquatic } & & Free-floating & \multirow{4}{*}{ Indigenous / alien } \\
\hline & & Floating & $\begin{array}{l}\text { Floating attached } \\
\text { (rooted) }\end{array}$ & \\
\hline & & Submerged & & \\
\hline & & Algal mat & & \\
\hline & \multirow{8}{*}{ Herbaceous } & Geophytes & & \multirow{8}{*}{$\begin{array}{l}\text { Indigenous / alien } \\
\text { / crop }\end{array}$} \\
\hline & & Grasses & & \\
\hline & & Herbs/forbs & & \\
\hline & & \multirow{5}{*}{$\begin{array}{l}\text { Sedges/rushes } \\
\text { Reeds }- \\
\frac{\text { Restios }}{\text { Palmiet }}--\end{array}$} & $\overline{\text { Sedges }}$ & \\
\hline & & & Rushes & \\
\hline & & & & \\
\hline & & & & \\
\hline & & & & \\
\hline & Shrubs/Thicket & & & Indigenous / alien \\
\hline & \multirow[t]{3}{*}{ Forest } & \multirow{2}{*}{ Riparian forest } & $\begin{array}{l}\text { Upper River riparian } \\
\text { forest }\end{array}$ & \multirow{3}{*}{$\begin{array}{l}\text { Indigenous / alien } \\
\text { / plantation }\end{array}$} \\
\hline & & & $\begin{array}{l}\overline{\text { Lower River riparian }} \\
\text { forest }\end{array}$ & \\
\hline & & $\begin{array}{l}\text { Forested wetland } \\
\text { (swamp forest) }\end{array}$ & & \\
\hline
\end{tabular}

Figure 4

Summary of the categories included for the different Descriptors at Level 6

The classification of inland aquatic ecosystems at Levels 1 to 4 of the classification system is likely to be consistent, typically changing only over relatively long periods (decades or longer) or as a result of dramatic disturbances. The same is generally true for the Hydrological Regime at Level 5. In contrast, a number of the features that are classified at Level 6 may change naturally in space and over relatively short time periods (i.e. type and cover of vegetation, substratum, and water quality aspects such as salinity and $\mathrm{pH}$ ). In order to minimise inconsistencies that might result from these natural variations, it is thus important to record the time of year in which these more dynamic features are categorised when applying the classification system. Features that may vary seasonally (e.g. salinity) should preferably be categorised in both the wet and dry seasons.

The designing of the classification system to be centred around the identification of HGM Units (and the categorisation of the Hydrological Regime to determine Functional Units) does limit the ability to classify an inland aquatic ecosystem upfront on the basis of structural features (e.g. as a swamp forest, peatland, saline pan and such like ecosystem types). Application of the Descriptors at Level 6, however, allows for this where sufficient information is available. Two real-world examples from the iSimanagaliso Wetland Park (KwaZulu-Natal), both of which form part of a peatland complex, illustrate the use of selected descriptors to capture information relating to important structural features. These are the Mfabeni Swamp Forest and the adjacent Mfabeni Sedge Reed Fen. Both of these inland wetlands have the same Regional Setting and Landscape Unit, as classified at Level 2 (Natal Coastal Plain Ecoregion) and Level 3 (Valley Floor), respectively. From Level 4 onwards, however, the classification of the two wetlands differs (except for the classification of the substratum type), as follows:

- Swamp Forest = mostly Channelled Valley-Bottom Wetland (Level 4); mostly Permanently Inundated and Littoral(Level 5); 'organic soil - peat' and 'vegetated - forest - forested wetland (swamp forest)' (Level 6)

- Sedge Reed Fen = Unchannelled Valley-Bottom Wetland or Flat (Level 4), depending on one's interpretation of the flow dynamics and landscape setting; mostly Seasonally Inundated and Permanently Saturated (Level 5); 'organic soil - peat' and 'vegetated - herbaceous - sedges/rushes sedges' (Level 6) 


\section{FUTURE RESEARCH NEEDS}

An important area for future research is to identify or develop the most appropriate spatial frameworks for particular purposes or for particular broad ecosystem types (e.g. rivers vs. wetlands vs. open waterbodies), as applied at Level 2 of the classification system. Some of the options that could be explored as a starting point to this research are key historical attempts to create a regional framework for the study of inland water ecosystems in the country such as Harrison's (1959) hydrobiological regions and the regional groupings for river ecosystems put forward by Noble and Hemens (1978), or more recent spatial frameworks such as Allanson et al.'s (1990) limnological regions; Cowan's (1995) wetland regions; Brown et al.'s (1996) bioregions, biogeographic regions and topographic zones for rivers; Mucina and Rutherford's (2006) biomes, bioregions, vegetation groups and vegetation types; and/or Partridge et al.'s (2010) geomorphic provinces (adapted from the original geomorphic provinces of King, 1967). Other options that could be tested as potential spatial frameworks are geological and/ or hydrogeological maps, which are available at various spatial scales. The appropriateness and usefulness of Kleynhans et al.'s (2005) ecoregions for application to aquatic ecosystems other than rivers should also be explored, as should the refinement of the NFEPA WetVeg Groups.

A research need in relation to the categorisation of Landscape Units (at Level 3 of the classification system) is the refinement of the definitions and conversion of the existing text-based descriptive definitions into more quantitative (or at least quantifiable) definitions with standardised, regionspecific, terrain-definable ranges or thresholds for various parameters (such as gradient, relief, area, relative proximity) that can be used in the GIS-based modelling of landscape settings (Thompson, 2009). This would assist greatly in improving the consistency and robustness of the automation of the classification system for national- and regional-scale initiatives. The degree to which HGM Types are associated with particular Landscape Units should also be explored, including an investigation as to whether such associations vary between different regions. A related aspect that requires further research is to test whether inland aquatic ecosystems within the same landscape setting function similarly to one another and whether there are differences in the functioning of aquatic ecosystems located in different landscape settings, which is one of the assumptions of the proposed classification system.

One of the most important research needs relating to the classification of inland aquatic ecosystems is to test whether aquatic ecosystems of the same HGM Type do actually function in a similar manner and, as importantly, whether there is a significant difference in the functional characteristics of the different HGM Types (e.g. Floodplain vs. Channelled ValleyBottom Wetland). These are fundamental assumptions of the HGM approach to classification, which still require verification in the South African context despite the fact that HGM-based classification systems have been used increasingly for inland aquatic ecosystems in the country, particularly wetlands, over the past 5 to 10 years.

Previous research initiatives relating to the development and use of classification systems for inland aquatic ecosystems in the country (e.g. O'Keeffe et al., 1994; Eekhout et al., 1997) have highlighted the simple truth that the predictions and extrapolations made from the groupings generated by a classification system will only ever be as accurate and useful as the expertise and information available for the particular ecosystems in a region. In the context of the classification system presented in the current paper, there is a dire need for the field-based collection of detailed data on the hydrogeomorphic and ecological characteristics of inland aquatic ecosystems, particularly for different types of wetlands in different regions, as a means of testing whether the HGM Types of the classification system adequately reflect ecosystem functioning.

\section{ACKNOWLEDGEMENTS}

The following people and organisations are gratefully acknowledged for their input and assistance into the development of the classification system:

- FCG and FRU colleagues

- Donovan Kotze

- Fred Ellery

- Mark Rountree

- Pete Illgner

- Retief Grobler

- Piet-Louis and Althea Grundling

- Maitland Seaman

- WRC and SANBI for funding the various phases of this project

\section{REFERENCES}

ALLAN DG, SEAMAN MT and KALETJA B (1995) The endorheic pans of South Africa. In: Cowan GI (ed.) Wetlands of South Africa. Department of Environmental Affairs and Tourism, Pretoria. 75-101.

ALLANSON BR, HART RC, O'KEEFFE JH and ROBARTS RD (1990) Inland waters of Southern Africa: an ecological perspective. Monogr. Biol. 64. Kluwer Academic Publishers, Dordrecht.

BEGG G (1986) The wetlands of Natal (Part 1). An overview of their extent, role, and present status. Natal Town and Regional Planning Report, Volume 68. The Natal Town and Regional Planning Commission, Pietermaritzburg. $115 \mathrm{pp}$

BREEN CM (1988) Wetlands classification. In: Walmsley RD and Boomker EA (eds.) Inventory and Classification of Wetlands in South Africa. Proceedings of a workshop held at the Hydrological Research Institute, Roodeplaat, 26-27 April 1988. Occasional Report No. 34, Ecosystem Programmes, Foundation for Research Development, CSIR, Pretoria. 76-85.

BREEN CM and BEGG GW (1989) Conservation status of southern African wetlands. In: Huntley BJ (ed.) Biotic Diversity in Southern Africa: Concepts and Conservation. Oxford University Press, Cape Town. 254-263.

BRINSON MM (1993) A hydrogeomorphic classification for wetlands. Technical Report WRP-DE-4, US Army Engineer Waterways Experiment Station, Vicksburg, MS

BROWN CA, EEKHOUT S and KING JM (1996) National Biomonitoring Programme for Riverine Ecosystems: Proceedings of Spatial Framework Workshop. NBP Report Series No. 2. Institute for Water Quality Studies, Department of Water Affairs and Forestry, Pretoria.

CLARK B (2008) National wetland inventory: Development of a wetland classification system for South Africa. Evaluation of an updated version of the wetland classification system: marine wetlands. Consultancy report prepared by Anchor Environmental for the Freshwater Consulting Group on behalf of the South African National Biodiversity Institute, June 2008.

COWAN GI (1995) Wetland regions of South Africa. In: Cowan GI (ed.) Wetlands of South Africa. Department of Environmental Affairs and Tourism, Pretoria. 21-31.

COWAN GI and VAN RIET WA (1998) Directory of South African wetlands. Department of Environmental Affairs and Tourism, Pretoria.

COWARDIN LM, CARTER V, GOLET FC and LAROE ET (1979) Classification of wetlands and deepwater habitats of the United States. FWS-OBS-79-31. US Fish and Wildlife Service, Washington, DC. 
DAVIDSON NC and FINLAYSON CM (2007) Earth observation for wetland inventory, assessment and monitoring. Aquat. Conserv. Mar. Freshwater Ecosyst. 17 219-228.

DELY JL, KOTZE DC, QUINN NW and MANDER JJ (1999) A pilot project to compile an inventory and classification of wetlands in the Natal Drakensberg Park. Prepared for the South African Wetlands Conservation Programme, Department of Environmental Affairs and Tourism, Pretoria.

DWAF (DEPARTMENT OF WATER AFFAIRS AND FORESTRY, SOUTH AFRICA) (2005) A practical field procedure for identification and delineation of wetlands and riparian areas. Department of Water Affairs and Forestry, Pretoria.

DWAF (DEPARTMENT OF WATER AFFAIRS AND FORESTRY, SOUTH AFRICA) (2007a) Development of the Water Resource Classification System (WRCS). First Edition. Volume 1: Overview and 7-step classification procedure. Chief Directorate: Resource Directed Measures, Department of Water Affairs and Forestry, Pretoria.

DWAF (DEPARTMENT OF WATER AFFAIRS AND FORESTRY, SOUTH AFRICA) (2007b) Manual for the assessment of a Wetland Index of Habitat Integrity for South African floodplain and channelled valley bottom wetland types. Rountree M (ed.), Todd CP, Kleynhans CJ, Batchelor AL, Louw MD, Kotze D, Walters D, Schroeder S, Illgner P, Uys M and Marneweck GC. Report No. N/0000/00/WEI/0407. Resource Quality Services, Department of Water Affairs and Forestry, Pretoria.

DE ROECK ER, VERHOEST NEC, MIYA MH, LIEVENS H, BATELAAN O, THOMAS A AND BRENDONCK L (2008) Remote sensing and wetland ecology: a South African case study. Sensors $\mathbf{8}$ 3542-3556.

DINI J, COWAN G and GOODMAN P (1998) South African national wetland inventory. Proposed wetland classification system for South Africa. First Draft, August 1998. South African Wetlands Conservation Programme, Department of Environmental Affairs and Tourism, Pretoria.

DINI JA and COWAN GI (2000) Classification system for the South African Wetland Inventory. Second Draft, June 2000. South African Wetlands Conservation Programme, Department of Environmental Affairs and Tourism, Pretoria.

DRIVER A, NEL JL, SNADDON K, MURRAY K, ROUX DJ, HILL L, SWARTZ ER, MANUEL J and FUNKE N (2011) Implementation manual for freshwater ecosystem priority areas. WRC Report No. 1801/1/11. Water Research Commission, Pretoria.

DRIVER A, SINK KJ, NEL JL, HOLNESS S, VAN NIEKERK L, DANIELS F, JONAS Z, MAJIEDT PA, HARRIS L and MAZE K (2012) National Biodiversity Assessment 2011: An assessment of South Africa's biodiversity and ecosystems. Synthesis Report. South African National Biodiversity Institute and Department of Environmental Affairs, Pretoria.

EEKHOUT S, KING JM and WACKERNAGEL A (1997) Classification of South African Rivers, Volume 1. Department of Environmental Affairs and Tourism, Pretoria.

ELLERY WN, GRENFELL MC, GRENFELL S, KOTZE DC, MCCARTHY TS, TOOTH S, GRUNDLING P-L, BECKEDAHL H, LE MAITRE D and RAMSAY L (2008) WET-Origins: Controls on the distribution and dynamics of wetlands in South Africa. WRC Report No. TT 334/08. Water Research Commission, Pretoria.

EWART-SMITH JL, OLLIS DJ, DAY JA and MALAN HL (2006) National wetland inventory: Development of a wetland classification system for South Africa. WRC Report No. KV 174/06. Water Research Commission, Pretoria

FARINHA JC, ARAÚJO PR, SILVA EP, CARVALHO S, FONSECA E and LAVINAS C (2005) MedWet habitat description system (Version 2005). Instituto da Conservação da Natureza (ICN) / Centro de Zonas Húmidas.

FINLAYSON CM and VAN DER FALK AG (1995) Wetland classification and inventory: a summary. Vegetatio 118 185-192.

FINLAYSON CM, BEGG GW, HOWES J, DAVIES J, TAGI K and LOWRY J (2002) A manual for an inventory of Asian wetlands: Version 1.0. Wetlands International Global Series 10, Kuala Lumpur, Malaysia.

FRISSELL CA, LISS WJ, WARREN CE and HURLEY MD (1986) A hierarchical framework for stream classification: Viewing streams in a watershed context. Environ. Manage. 10 199-214.

FROUDE VA and BEANLAND RA (1999) Review of environmental classification systems and spatial frameworks. Report prepared for Ministry for the Environment, New Zealand Government, September 1999. Report Reference No. TR88. URL: http://www. mfe.govt.nz/publications/ser/metadata/env-class/index.html (Accessed 16 November 2005).

GELDENHUYS JN (1982) Classification of pans in the western Orange Free State according to vegetation structure, with reference to avifaunal communities. S. Afr. J. Wildlife Res. 12 55-62.

HARRISON AD (1959) General statement on South African hydrobiological regions. National Institute for Water Research Report No. 1 Project 6.8H. CSIR, Pretoria.

HART RC (1995) South African coastal lakes. In: Cowan GI (ed.) Wetlands of South Africa. Department of Environmental Affairs and Tourism, Pretoria. 103-130.

HART BT and CAMPBELL IC (1994) Ecological river classification scheme for Australia. In: Uys MC (ed.) Classification of Rivers and Environmental Health Indicators. Proceedings of a joint South African / Australian workshop, 7-14 February 1994, Cape Town, South Africa. WRC Report No. TT 63/94. Water Research Commission, Pretoria. 87-100.

JONES MGW (2002) Developing a classification system for Western Cape Wetlands. MSc thesis, University of Cape Town.

JONES MGW and DAY JA (2003) A field classification system for the wetlands of the Western Cape. Freshwater Research Unit, University of Cape Town.

KING JM, DE MOOR FC and CHUTTER FM (1992) Alternative ways of classifying rivers in southern Africa. In: Boon PJ, Calow P and Petts GE (eds.) River Conservation and Management. John Wiley \& Sons, Chichester. 213-228.

KING LC (1967) South African Scenery: A Textbook of Geomorphology ( $3^{\text {rd }}$ edn). Oliver and Boyd, Edinburgh and London. 308 pp.

KLEYNHANS CJ, THIRION C and MOOLMAN J (2005) A Level 1 Ecoregion Classification System for South Africa, Lesotho and Swaziland. Report No. N/0000/00/REQ0104. Resource Quality Services, Department of Water Affairs and Forestry, Pretoria.

KOTZE DC (1999) A system for supporting wetland management decisions. PhD thesis, University of Natal: Pietermaritzburg.

KOTZE DC, BREEN CM and KLUG JR (1994) WETLAND-USE: a decision support system for managing wetlands. WRC Report No 501/2/94. Water Research Commission, Pretoria.

KOTZE DC, ELLERY WN, MACFARLANE DM and JEWITT GPW (2012) A rapid assessment method for coupling anthropogenic stressors and wetland ecological condition. Ecol. Indic. 13 284-293.

KOTZE DC, MARNEWECK GC, BATCHELOR AL, LINDLEY DS and COLLINS NB (2008) WET-EcoServices: A technique for rapidly assessing ecosystem services supplied by wetlands. WRC Report No. TT 339/09. Water Research Commission, Pretoria.

LEHNER B and DÖLL P (2004) Development and validation of a global database of lakes, reservoirs and wetlands. J. Hydrol. 296 1-22.

LOMBARD AT, STRAUSS T, HARRIS J, SINK K, ATTWOOD C and HUTCHINGS L (2005) South African National Spatial Biodiversity Assessment 2004. Technical Report, Volume 4: Marine Component. South African National Biodiversity Institute, Pretoria.

LONGMORE JL (2001) The Geomorphology of Wetlands in the Upper Mooi River Catchment, KwaZulu-Natal. MSc thesis, University of Natal: Pietermaritzburg.

MACFARLANE DM, KOTZE DC, ELLERY WN, WALTERS D, KOOPMAN V, GOODMAN P and GOGE C (2008) WET-Health: A technique for rapidly assessing wetland health. WRC Report No. TT 340/08. Water Research Commission, Pretoria.

MARNEWECK GC and BATCHELOR AL (2002) Wetland classification, mapping and inventory. Chapter 5. In: Palmer RW, Turpie J, Marneweck GC and Batchelor AL (eds.) Ecological and economic evaluation of wetlands in the Upper Olifants River Catchment. WRC Report No. K5/1162. Water Research Commission, Pretoria. $55-67$.

MCCARTHY TS and HANCOX PJ (2000) Wetlands. In: Partridge TC and Maud RR (eds.) The Cenozoic of Southern Africa. Oxford 
University Press, New York. 218-235.

MORANT PD (1981) Wetland classification: a review of existing wetland classification systems and their applicability in Southern Africa. MSc thesis, University of Cape Town.

MORANT PD (1983) Wetland classification: towards an approach for southern Africa. J. Limnol. Soc. S. Afr. 9 (2) 76-84.

MUCINA L and RUTHERFORD MC (eds.) (2006) The Vegetation of South Africa, Lesotho and Swaziland. Strelitzia 19. South African National Biodiversity Institute, Pretoria.

NAIMAN RJ (1998) Biotic stream classification. In: Naiman RJ and Bilby RE (eds.). River Ecology and Management: Lessons from the Pacific Coastal Ecoregion. Springer-Verlag, New York. 97-119.

NAIMAN RJ, LONZARICH DG, BEECHIE TJ and RALPH SC (1992) General principles of classification and the assessment of conservation potential in rivers. In: Boon PJ, Calow P and Petts GE (eds.) River Conservation and Management. John Wiley \& Sons, Chichester. 93-123.

NEL JL and DRIVER A (2012) South African National Biodiversity Assessment 2011: Technical Report. Volume 2: Freshwater Component. CSIR Report Number CSIR/NRE/ECO/IR/2012/0022/A, Council for Scientific and Industrial Research, Stellenbosch.

NEL JL, MURRAY KM, MAHERRY AM, PETERSEN CP, ROUX DJ, DRIVER A, HILL L, VAN DEVENTER H, FUNKE N, SWARTZ ER, SMITH-ADAO LB, MBONA N, DOWNSBOROUGH L and NIENABER S (2011a) Technical Report for the Freshwater Ecosystem Priority Areas Project. WRC Report No. 1801/2/11. Water Research Commission, Pretoria.

NEL JL, DRIVER A, STRYDOM WF, MAHERRY A, PETERSEN C, HILL L, ROUX DJ, NIENABER S, VAN DEVENTER H, SWARTZ E and SMITH-ADAO LB (2011b) Atlas of Freshwater Ecosystem Priority Areas in South Africa: Maps to support sustainable development of water resources. WRC Report No. TT 500/11. Water Research Commission, Pretoria.

NOBLE RG (1974) An evaluation of the conservation status of aquatic biotopes. Koedoe 17 71-83.

NOBLE RG and HEMENS J (1978) Inland Water Ecosystems in South Africa - a Review of Research Needs. South African National Scientific Programmes Report No. 34. Council for Scientific and Industrial Research, Pretoria. 148 pp.

O'KEEFFE J, KING J and EEKHOUT S (1994) The characteristics and purposes of river classification. In: Uys MC (ed.) Classification of rivers and environmental health indicators. Proceedings of a joint South African / Australian workshop, 7-14 February 1994, Cape Town, South Africa. WRC Report No. TT 63/94. Water Research Commission, Pretoria. 9-17.

OLLIS DJ, DALLAS HF, ESLER KJ and BOUCHER C (2006) Bioassessment of the ecological integrity of river ecosystems using aquatic macroinvertebrates: an overview with a focus on South Africa. Afr. J. Aquat. Sci. 31 (2) 205-227.

OLLIS DJ and EWART-SMITH JL (2006) Literature review. Appendix 1. In: Ewart-Smith JL, Ollis DJ, Day JA and Malan HL. National wetland inventory: Development of a wetland classification system for South Africa. WRC Report No. KV 174/06. Water Research Commission, Pretoria. 51-90.

OLLIS DJ, MACFARLANE DM, JOB NM, SIEBEN EJJ and SNADDON CD (2009a) Further development of a proposed national wetland classification system for South Africa. Primary project report. Prepared by the Freshwater Consulting Group (FCG) for the South African National Biodiversity Institute (SANBI).

OLLIS DJ, JOB NM, MACFARLANE DM and SIEBEN EJJ (2009b) Further development of a proposed national wetland classification system for South Africa. Supplementary project report: application and testing of proposed national wetland classification system. Prepared for the South African National Biodiversity Institute (SANBI).

OLLIS DJ, SNADDON CD, JOB NM and MBONA N (2013) Classification system for wetlands and other aquatic ecosystems in South Africa. User manual: Inland systems. SANBI Biodiversity Series 22. South African National Biodiversity Institute, Pretoria.

PARTRIDGE TC, DOLLAR ESJ, MOOLMAN J and DOLLAR LH (2010) Geomorphic provinces of South Africa, Lesotho and Swaziland: A physiographic subdivision for earth and environmental scientists. Trans. R. Soc. S. Afr. 65 (1) 1-47.

REBELO L-M (2010) Eco-hydrological characterization of inland wetlands in Africa using L-Band SAR. IEEE J. Selected Topics Appl. Earth Obs. Remote Sens. 3 (4) 554-559.

REBELO L-M, FINLAYSON CM and NAGABHATLA N (2009) Remote sensing and GIS for wetland inventory, mapping and change analysis. J. Environ. Manage. 90 2144-2153.

RSA (REPUBLIC OF SOUTH AFRICA) (1998) National Water Act. Act No. 36 of 1998. Government Gazette 19182. Government Printer, Cape Town.

RIVERS-MOORE NA and GOODMAN PS (2010) River and wetland classifications for freshwater conservation planning in KwaZuluNatal, South Africa. Afr. J. Aquat. Sci. 35 (1) 61-72.

ROGERS KH (1995) Riparian wetlands. In: Cowan GI (ed.) Wetlands of South Africa. Department of Environmental Affairs and Tourism, Pretoria. 41-52.

ROGERS KH (1997) Freshwater wetlands. In: Cowling RM, Richardson DM and Pierce SM (eds.) Vegetation of Southern Africa. Cambridge University Press, Cambridge. 322-347.

ROSGEN DL (1994) A classification of natural rivers. Catena 22 169-199.

ROWNTREE KM and WADESON RA (1999) A Hierarchical Geomorphological Model for the Classification of Selected South African Rivers. WRC Report No. 497/1/99. Water Research Commission, Pretoria. 334 pp.

ROWNTREE KM and WADESON RA (2000) Field Manual for Channel Classification and Condition Assessment. NAEBP Report Series No. 13. Institute for Water Quality Studies, Department of Water Affairs and Forestry, Pretoria.

ROWNTREE KM, WADESON RA and O'KEEFFE J (2000) The development of a geomorphological classification system for the longitudinal zonation of South African rivers. S. Afr. Geogr. J. 82 (3) $163-172$.

RUTHERFORD MC, MUCINA L and POWRIE LW (2006) Biomes and Bioregions of Southern Africa. In: Mucina L and Rutherford MC (eds.). The Vegetation of South Africa, Lesotho and Swaziland. Strelitzia 19. South African National Biodiversity Institute, Pretoria. Pp. 31-51.

SCOTT DA and JONES TA (1995) Classification and inventory of wetlands: A global overview. Vegetatio 118 3-16.

SEMENIUK CA and SEMENIUK V (1995) A geomorphic approach to global classification for inland wetlands. Vegetatio 118 103-124.

SIEBEN EJJ, ELLERY WN, KOTZE DC and ROUNTREE M (2011) Hierarchical spatial organization and prioritization of wetlands: a conceptual model for wetland rehabilitation in South Africa. Wetlands Ecol. Manage. 19 209-222.

SINK KJ, HOLNESS S, HARRIS L, MAJIEDT PA, ATKINSON L, ROBINSON T, KIRKMAN S, HUTCHINGS L, LESLIE R, LAMBERTH S, KERWATH S, VON DER HEYDEN S, LOMBARD AT, ATTWOOD C, BRANCH G, FAIRWEATHER T, TALJAARD S, WEERTS S, COWLEY P, AWAD A, HALPERN B, GRANTHAM H and WOLF T (2012) National Biodiversity Assessment 2011: Technical Report. Volume 4: Marine and Coastal Component. South African National Biodiversity Institute, Pretoria.

THOMPSON M (2009) Personal communication, 2 February 2009. Mr Mark Thompson, Director: Environmental Remote Sensing Applications, GeoTerraImage (GTI) (Pty) Ltd, PO Box 295, Persequor TechnoPark, Pretoria 0020, South Africa.

THOMPSON M, MARNEWECK G, BELL S, KOTZE D, MULLER J, COX D and CLARK R (2002) A methodology proposed for a south african national wetland inventory. Report prepared for South African Wetlands Conservation Programme, Department of Environmental Affairs and Tourism, Pretoria.

TINER RW (1999) Wetland Indicators: A Guide to Wetland Identification, Delineation, Classification, and Mapping. Lewis Publishers, Boca Raton. 392 pp.

TINER RW (2003) Dichotomous keys and mapping codes for wetland landscape position, landform, water flow path, and waterbody type descriptors. US Fish and Wildlife Service, National Wetlands Inventory Program, Northeast Region, Hadley, MA. 44 pp.

TINER RW (2011) Dichotomous keys and mapping codes for wetland landscape position, landform, water flow path, and waterbody type 
descriptors: Version 2.0. U.S. Fish and Wildlife Service, National Wetlands Inventory Program, Northeast Region, Hadley, MA. 51 pp. TURPIE J (2005). South African National Spatial Biodiversity

Assessment 2004. Technical Report, Volume 3: Estuary Component. South African National Biodiversity Institute, Pretoria.

TURPIE J, ADAMS A, WHITFIELD A and VAN NIEKERK L (2008)

Evaluation of the estuarine component of the draft wetland classification system for the South African national wetland inventory. Consultancy report prepared for the Freshwater Consulting Group on behalf of the South African National Biodiversity Institute, June 2008.

VAN NIEKERK L and TURPIE JK (eds.) (2012) National

Biodiversity Assessment 2011: Technical Report. Volume 3: Estuary Component. CSIR Report Number CSIR/NRE/ECOS/ ER/2011/0045/B. Council for Scientific and Industrial Research, Stellenbosch.

WHITFIELD AK (1992) A characterization of southern African estuarine systems. S. Afr. J. Aquat. Sci. 18 (1/2) 89-103. 